Hybrid binders: A journey from the past to a sustainable future (opus caementicium futurum)

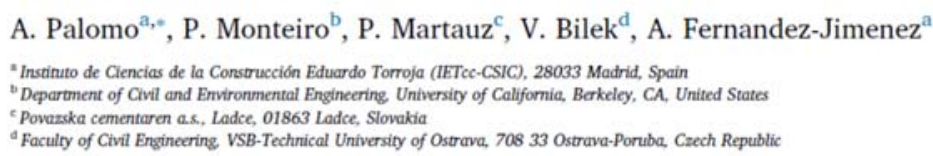

\title{
HYBRID BINDERS: A JOURNEY FROM THE PAST TO A SUSTAINABLE FUTURE (OPUS CAEMENTICIUM FUTURUM)
}

\author{
${ }^{1}$ A. Palomo, ${ }^{2}$ P. Monteiro, ${ }^{3} P$. Martauz, ${ }^{4}$ V. Bilek and ${ }^{1} A$. Fernandez-Jimenez \\ ${ }^{1}$ Instituto de Ciencias de la Construcción Eduardo Torroja (IETcc-CSIC), 28033 \\ Madrid (Spain) \\ ${ }^{2}$ Department of Civil and Environmental Engineering, University of California, \\ Berkeley, CA, United States \\ ${ }^{3}$ Povazska cementaren a.s.,Ladce, 01863 Ladce (Slovakia) \\ ${ }^{4}$ Faculty of Civil Engineering, VSB-Technical University of Ostrava, 70833 Ostrava- \\ Poruba (Czech Republic)
}

\begin{abstract}
This article describes and interprets data drawn from a thorough characterisation of a series of cementitious materials. The materials addressed can be divided into three major groups: 1) cements/concretes from well-known and historically documented Roman constructions in Italy; 2) cements recently prepared in the laboratory simulating the compositions of Roman cements, stored for 6 months in environmental conditions similar to those to which the Roman materials have been exposed for 2000 years; 3 ) concretes prepared from an industrial cement manufactured 6 years ago applying today's knowledge of hybrid cements. An analysis of all the data presented in this article has led its authors to conclude that, conceptually speaking, ancient Roman cements can be identified with modern hybrid 'portland-alkaline' materials. That conceptual identity is based on the detection of the same cementitious phases in the two types of cements (Roman and Hybrid) and naturally of the inclusion of alkalis in the structures of some of the phases observed.
\end{abstract}

Keywords: Roman cement, hybrid cement, C-A-S-H gel, N-A-S-H gel, AlTobermorite, zeolites. 


\section{1.- INTRODUCTION}

The International Congress on the Chemistry of Cement (ICCC) has always afforded a splendid opportunity for reflections on the developments occurred in the four years since the preceding congress (Beijing 2015 in the present case). This year, moreover, the ICCC is celebrating its $100^{\text {th }}$ anniversary in Prague. In other words, the international scientific community has been uninterruptedly generating fundamental knowledge and contributing in industrial progress on cements for at least 100 years. However, a century of constant advances and successes has paradoxically engendered a complex environmental challenge (1-2): the world manufacture of Portland cement generates vast amounts of $\mathrm{CO}_{2}$ emission $(7 \%$ to $9 \%$ of the planet-wide total).

A possible solution to the environmental problem posed by that mass consumption of Portland cement may be inspired by a precise understanding of the fundamental chemical properties of the cements made by the Romans 2000 years ago. Who could question the exceptional resistance and durability of those materials?

Roman marine structures were built essentially with concrete bearing hydraulic lime, volcanic ash, and aggregate. Those structures have remained practically intact for 2000 years, despite being wholly or partially submerged in seawater [3]. Today's scientific community is certain that the astounding durability of Roman concrete exposed to seawater has much to do with the nature of the cementitious matrix developed over time: a scantly crystalline C-A-S-H or calcium aluminosilicate hydrate gel [4]; the uptake of certain chemical species such as $\mathrm{Cl}^{-}$or $\mathrm{SO}_{4}{ }^{2-}$ (from seawater) into stable crystalline phases [5]; and the precipitation of Altobermorite and certain zeolites in pores and voids in the cementitious matrix [6]. The reality is that the service life of Roman marine structures is approximately two orders of magnitude longer than the marine structures made with portland cement. Note, however, that the presence of steel reinforcement corrosion naturally induces premature deterioration in modern structures [7] while the ancient Romans did not use steel reinforcement. 
In 2001 Alonso and Palomo [8], studying the alkaline activation of blends of metakaolin + lime, concluded that the simultaneous precipitation of different types of cementitious gels (C-A-S-H and N-A-S-H) could be induced by simply modifying the $\mathrm{pH}$ at which these blends were hydrated. Since then, great effort has been invested in the pursuit of a fuller understanding of the chemistry of hybrid cements consisting in portland+alkaline cements [9-11], i.e., blends of materials able to simultaneously generate hydration products characteristic of portland (CS-H or C-A-S-H gel) and alkaline (N-A-S-H, N-(C)-A-S-H, zeolites, etc.) cements.

Technologically speaking, a blend of cementitious gels (amply studied in the literature, consult for instance [12-15]) can be engineered to develop a matrix with high strength and durability. Environmentally speaking, there is every indication that hybrid cements may significantly lower the consumption of Portland clinker and with it $\mathrm{CO}_{2}$ emissions [16-17].

This article was planned and written primarily to establish chemical, mineral and nano-structural parallels between ancient Roman and modern hybrid cements. In an attempt to phrase that intention in terms understandable to readers and explain the both the working hypotheses at issue and the information in place (in the literature and new data specifically generated on the occasion of this research), the authors have divided the text into three sections. Parts 2, 3 and 4 of the paper, while independent, are inter-connected around the notion of 'multi-gel precipitation'. In other words, when hydrated, all the cements discussed generate more than one type of cementitious gel (normally C-A-S-H-like gels with variable $\mathrm{Ca} / \mathrm{Si}$ and $\mathrm{Si} / \mathrm{Al}$ ratios), a certain fraction of which may be identified as (N,C)-A-S$\mathrm{H}$-like gels in light of the alkalis bound to their structure. The three sections are set out as follows.

Section 2) summarises the key properties of ancient Roman marine concrete (used 2000 years ago in such emblematic works as Portus Neronis or Portus Traiani, in Italy that are still standing) as inferred from the results delivered by sophisticated analytical techniques.

Section 3) discusses the progress made in the understanding of modern hybrid cements (brief literature review), along with recent findings on cements that 
'simulate' the mineral and chemical compositions of Roman binders after exposure to environmental conditions similar to those described in section 2, although obviously on a very different time scale. Section 3 also compares the data in sections 2 and 3, explaining the reasons why the authors deem some Roman cements to be, microstructurally and chemically speaking, very similar to modern hybrid 'portland-alkaline' cements.

Section 4) shows that modern hybrid Portland-Alkaline cements can be manufactured on an industrial scale with the facilities presently in place in Portland cement plants. It also contends that hybrid cements are a sustainable alternative to traditional portland cements and substantially improve some of the properties highly esteemed in modern construction (resistance to aggressive chemicals, etc.)

\section{2.- SOME LESSONS LEARNED FROM ANCIENT ROMAN CONCRETE}

The characterisation of ancient Roman concrete has received comprehensive attention over the years [18-22], but recent utilisation of synchrotron radiation techniques has provided new insights into its complex structure [4,6,23-26]. Many of these techniques have been also used to study various phases existing in geopolymers and cement reaction products including, C-(A-)S-H, Al-tobermorite, ettringite, katoite, and strätlingite, among others, [27-37].

\section{1.- Raw materials}

The use of limestone cement has been used in the Near East and Anatolia since the prepottery Neolithic Age. Hale 2008 [38] has suggested that the impetus to improve the technology of boiling and roasting of grains in the Near East may have led the way to the development of lime mortars. Although the Romans were not the first ancient society to add pozzolanic materials to lime mortar, they are responsible for the systematic use of pozzolan into concrete mixtures. In his classic book Architectura, Vitruvius described the use of volcanic rocks in the manufacture of ancient concrete: harenae fossiciae (pit sand) for inland constructions and pulvis (powder) for marine structures. Vitruvius observed that good harenae fossiciae "when rubbed in the hands it causes screech, .., it shouldn't be earthy but rough if wrapped in a white cloth, when 
shaken away, it has not left any dirt nor any earth in there". Pulvis was often associated with volcanic ash that, when "mixed with lime and rock fragments not only confers strength to the constructions, but is capable to solidify under water." [Vitruvius].

In the first century BCE, Pliny the Elder also realised very early on that volcanic ash afforded the lime used at the time with extraordinary properties: as soon as it was submerged in seawater it turned into a very solid stony mass that held back the waves (firem unum lapidem) and gained in strength day by day (Naturalis Historia 35.166).

In short, the chroniclers of historic materials were the first to pay tribute to the cementitious properties of natural pozzolans. Foremost among these siliceous and/or aluminous minerals are zeolites, opaline rocks and diatomaceous earth. Today they form part of the sizeable group of what are known as supplementary cementitious materials (SCMs), which also includes certain industrial by-products such as fly ash and slag, that are ever more frequently added to portland cements.

The mineralogy of the pozzolan has been studied in detail [18, 22, 39-44]. Recently, based on the observation that the ratios of several trace elements (i.e., $\mathrm{Zr}, \mathrm{Y}, \mathrm{Nb}, \mathrm{Ti}$, $\mathrm{Th}, \mathrm{Ta}$ ) are relatively insensitive to alteration processes, researchers [45-46] developed a robust method to identity the origin of the volcanic rock used in concrete. Using these trace-element fingerprinting and electron microprobe analysis on glasses, D'Ambrosio et al. (2015) [23] showed that the pulvis originated from the Phlegrean Fields volcanic deposits and, based on extensive experimental study, the authors made the compelling point that, due to the pozzolanic reaction, concrete made with any harena fossicia would have worked as well as the pulvis puteolanis for seawater structures.

Harena sine calce (sand without lime) is considered one of the best quotes of literature criticism, referring to a collection of pieces without cohesion. It has been attributed to Caligula criticising Seneca's work, and it showed that the importance of lime to "glue" pieces together was recognised even among non-experts in construction materials [47]. Vitruvius recommended a ratio of lime to pozzolan of 1:2 and for underwater and 1:3 for dry land construction, while Pliny the Elder suggested a ratio of 1:4 for the latter. Compared to the detailed characterisation of pozzolans, researchers have dedicated less time to the study of the origin of lime used in ancient Roman concrete [3 48-49]. Recent work by MacFarlane et al (2019) [50] has shown a significant presence of sulfur in the 
relict lime clasts of Roman marine concrete, indicating that the slaked lime was not made from pure limestone. The authors proposed that alkaline trachyte rocks of the Tyrrhenian volcanic provinces were used in the production of lime due to similarities in concentrations of sulfur, aluminium and rare-earth elements. This finding is relevant because such concentrations in sulfur and aluminates can have an impact in the chemical reactions with the pozzolan. There is a need to perform careful characterisation of the relict lime clasts existing in the matrix of ancient Roman concrete to establish the composition of the lime, sources of rocks that were used to produce the lime and the fluids used in the slaking process.

\subsection{Microstructure of ancient Roman concrete}

The interaction between seawater and OPC concrete generally concludes with corrosion of reinforcing steel, but sometimes this interaction causes expansive reactions [51]. However Portlandite is usually quickly consumed in reproductions of Roman concretes, where reinforcing steel does not exist. In other words, there are great conceptual differences between today's Portland concretes and Roman concretes that justify the different behaviours in their respective interactions with seawater. Thus, the Roman concretes existing in the Mediterranean region have been shown to contain reactive aggregates of volcanic nature (fine sand and also gravel), generally covered by a layer of zeolitic ore. These concretes have been exposed to seawater for 2000 years; and even if it is believed that the reactive process of pozzolans is well known in ancient concretes [4], reality is that no hypothesis have been yet established describing the postpozzolanic processes that have been controlling the chemistry of these materials for those two millennia, long after the Portlandite was totally consumed.

The Roman Maritime Concrete Survey (ROMACONS) project is the most comprehensive study of Roman marine concrete to date. The field program extracted cores samples from eleven locations throughout the Mediterranean; the book by [3] gives an inclusive and careful analysis of the project. Besides using classical methods, the microstructure of maritime concrete was also studied with synchrotron radiation by Jackson [4,6,24,25]. Currently, $76 \mathrm{~mm}$ cores from Santa Liberata, Baia, Caesarea Palestinae, Pompeiopolis, and Portus Traiani from the ROMACONS project are being studied, using a combination of lab X-ray microtomography, synchrotron radiation, and neutrons to characterise: (a) the nano/microstructure of the concrete samples with high- 
resolution soft X-ray ptychography; (b) in-situ crack propagation under load using synchrotron X-ray microtomography; (c) penetration of fluids imaged by neutrons; and (d) reaction product nano-spectroscopy. Figure 1(a) shows a typical cross section of an ancient Roman concrete used in the harbour of Santa Liberata. A detailed petrographic analysis is given by [48]. The tomographic cross section shows normal and porous (tuff) aggregates with relict lime clast well dispersed in a cementitious matrix. Some of these inclusions have large porosity and, in principle, could be a pathway for the crack propagation; however, preliminary tests indicate that the cracks are deflected both by the aggregates and the relict lime clasts (see Figure 1(c) for cracks in the interfacial transition zone). More experiments are underway to validate these observations for various samples tested under different uniaxial loading rates. It will also be useful to study the crack propagation under triaxial loads.

Figure 1: (a) Tomography of the $76 \mathrm{~cm}$-sample cored from Santa Liberata harbour; and (b) insertion device to test in-situ crack growth due to increasing loads. (The experiments were done at beamline 8.3.2 at the Advanced Light Source, in Berkeley, California.); (c) crack growth under compressive loads in a concrete sample from Pompeiopolis; and (d) an image of a diagonal cut through the cracked sample shown in Figure 1(c) (Images c and d courtesy of Ke Xu.).

Figure 2 shows a multi-scale imagining of ancient Roman concrete used in harbour of Santa Liberata. The main thrust of this research was to study the morphology of the relict lime clast and its topology inside the matrix. Starting with a low-resolution 3-D X-ray tomography (Figure 2(b)) of the core (Figure 2(a)), it was possible to visualize the spatial distribution of the various phases with $75 \mu \mathrm{m}$ voxel (Figure 2 (b)) and then focus on the relict lime clast with a higher spatial resolution $(10 \mu \mathrm{m}$ voxel size (Figs. 2 (c) and (d)). Various cross sections showing the dissolution process and the porosity in the relict lime clast are presented in Figure 2(d). After these experiments were performed, the relict lime clast was removed from the concrete and then imaged with voxel sizes of 2 and $0.8 \mu \mathrm{m}$ to indicate the complexity of the porous network. 
Figure 2: Multi-scale imaging of the Santa Liberata core. (a) photograph of the core; (b) three-dimensional reconstruction of the core using X-ray tomography at an energy of $150 \mathrm{KV}$ and $75 \mu \mathrm{m}$ voxel size; (c) tomographic detail of relict lime clast obtained at an energy of $150 \mathrm{KV}$ and $10 \mu \mathrm{m}$ voxel size; and (d) relict lime clast imaged with 2 and $0.8 \mu \mathrm{m}$ voxel size.

The next step in the multi-scale imaging was to characterize the nanostructure with spatial resolutions of less than $10 \mathrm{~nm}$. Using coherent diffraction patterns, soft X-ray ptychography allows a high spatial resolution morphological study, which has been successfully used in the characterisation of cementitious materials [28, 52-53]. Li et al. (2019) [32] studied the morphology of C-A-S-H using soft X-ray ptychographic imaging. The results indicate that: (a) C-A-S-H synthesised at 7 to $50{ }^{\circ} \mathrm{C}$ had similar morphology; and (b) C-A-S-H synthesised at $80^{\circ} \mathrm{C}$, and unlike the other samples, had a foil-predominant network (see Figure 3(a)), which was mostly likely associated with an increase of crystallinity and silicate chain polymerisation. Figure 3(b) shows that C-AS-H/Al-tobermorite from ancient Roman concrete has similar structure to C-A-S-H synthesised at $80^{\circ} \mathrm{C}$. All data processing, including pthychographic reconstruction, can be performed using the methods available in the SHARP-CAMERA software package (http://camera.lbl.gov).

Figure 3: 2D Ptychographic images of (a) $C$ - $(A-) S$-H equilibrated for 56 days at $80{ }^{\circ} \mathrm{C}$, $\mathrm{Ca} / \mathrm{Si}=1, \mathrm{Al} / \mathrm{Si}=0.1$, scale bar is $1 \mu \mathrm{m}$ (from Li et al. 2019) and (b) relict lime clast from the ancient concrete cored at Santa Liberata. Image obtained at beamline 5.3.1 at the Advanced Light Source in Berkeley, California (imagine courtesy of G. Geng).

Modern three-dimensional (3D) soft X-ray ptychography can generate 3D images with a spatial resolution of $11 \mathrm{~nm}$ confirmed by Fourier shell correlation and line-profiles and providing by the following reference [54]; however, even traditional soft X-ray nanotomography with a resolution of $30 \mathrm{~nm}$ can provide useful information. For instance, using a core obtained from Baianus Sinus (via the ROMACONS project), Jackson et al. 2013 [4] collected clusters of Al-tobermorite crystals from a relict lime clast and analysed their mathematical morphology using nanoscale tomography (see Figure 4). The 3D tomographic reconstruction shows the platy and elongated $1-2 \mu \mathrm{m}$ crystals of Al-tobermorite. To further characterize the topological features of the assemblage of the crystals, a 3D skeleton graph was created and its connected number computed. Strongly disconnected networks have negative values of connected numbers 
while well-connected networks have values greater than 0.5 ; therefore, the measured value of 0.65 for the Al-tobermorite cluster indicates a well-connected solid mass. These Al-tobermorite nanocrystals were studied by ${ }^{29} \mathrm{Si}$ MAS NMR. The results indicate that: (a) tetrahedral alumina was present in the silicate chain, $\mathrm{Q}^{2}(1 \mathrm{Al})$, and branch, $\mathrm{Q}^{3}(1 \mathrm{Al})$ or $\mathrm{Q}^{3}(2 \mathrm{Al})$; (b) the mean chain length was 13.97; and (c) the $\mathrm{Ca} / \mathrm{Si}$ ratio estimated by the $\mathrm{Q}^{2} / \mathrm{Q}^{3}$ ratio was 0.9 , which was confirmed by EPMA to give a value of 0.92 .

Figure 4: Al-tobermorite crystal clusters in a relict lime clast found in ancient Roman concrete from Baianus Sinus: (a) typical soft X-ray transmission image obtained with $280 \mathrm{eV}$ incident X-ray; (b) high-resolution nanotomography reconstruction obtained with $510 \mathrm{eV}$ incident X-ray; and (c) associated topological skeleton (from Jackson et al. 2013 [4]).

In addition to characterised maritime Roman concrete, synchrotron radiation was also used to study imperial roman architectural mortar. Jackson et al. (2014) [24] analysed the microstructure of the concrete used in the construction of Trajan's Markets by synchrotron X-ray microdiffraction and scanning electron microscopy. Microdiffraction of the matrix identified the in-situ crystallisation of the following minerals (see Figure 5): (a) hydrotalcite $\mathrm{Mg}_{6} \mathrm{Al}_{2}(\mathrm{OH})_{16}\left[\mathrm{CO}_{3}\right] \cdot 4 \mathrm{H}_{2} \mathrm{O}$; (b) strätlingite, $\mathrm{Ca}_{2} \mathrm{Al}(\mathrm{AlSi}) \mathrm{O}_{2}(\mathrm{OH})_{10}$. $2.25 \mathrm{H}_{2} \mathrm{O}$; (c) katoite $\left[\mathrm{Ca}_{3} \mathrm{Al}_{2}\left(\mathrm{SiO}_{4}\right) 1.5(\mathrm{OH})\right.$; and (d) åkermanite $\left[\mathrm{Ca}_{2} \mathrm{Mg}\left(\mathrm{Si}_{2} \mathrm{O}_{7}\right)\right]$, in solid solution with gehlenite $\left[\mathrm{Ca}_{2} \mathrm{Al}_{2}\left(\mathrm{SiO}_{7}\right)\right]$.

The results indicate that $\mathrm{C}-\mathrm{A}-\mathrm{S}-\mathrm{H}$, the main cementitious phase, had $\mathrm{Ca} /(\mathrm{Si}+\mathrm{Al})$ values in the range of 0.45 to 0.75 , and that strätlingite plates were observed in various interfacial transition zones (ITZ) in the cementitious matrix. The authors propose that these strätlingite plates reinforce the porous weak zones. The precipitation of these crystals takes a long time and involves the dissolution of lime, the presence of alkalirich scorie, halloysite, phillipsite, and chabazite. The hypothesis of in-situ mineral fibre reinforcement is quite relevant to modern concrete composed of blended cements and alkali-activate systems. Vanorio and Kanitpanyacharoen (2015) [55] further extended this concept by carefully demonstrating that the caprock of the Campi Flegrei Caldera (near the Italian town of Pozzuoli) - above the seismogenic area-has a fibril-rich matrix that results from lime-pozzolanic reactions between the calc-silicate rock and the lime-rich fluids from hydrothermal decarbonation. The authors proposed that the 
mineral fibre reinforcement increases the mechanical properties of the caprock, leading to a higher ductility and fracture toughness.

In a recent synchrotron X-ray microdiffraction study of samples from the ancient Roman marine structures at Baianus Sinus, Portus Neronis, and Portus Cosanus, Jackson et al. (2017) [6] reported that (a) Al-tobermorite was also present in the leached perimeters of feldspar inclusions and zeolitised pumice vesicles, and (b) in-situ phillipsite can occur in relict pores. The authors have provided insightful hypotheses for the post-pozzolanic crystallisation of phillipsite and Al-tobermorite in concrete exposed to seawater and ambient temperature.

The general formula for tobermorite minerals is $\mathrm{Ca}_{4+\mathrm{x}}\left(\mathrm{Al}_{\mathrm{y}} \mathrm{Si}_{6-\mathrm{y}}\right) \mathrm{O}_{15+2 x-\mathrm{y}} \cdot 5 \mathrm{H}_{2} \mathrm{O}$, where $\mathrm{x}=1$ and $\mathrm{y}=2$ [56]. Nonetheless, most natural rocks contain $\mathrm{Al}$ in their microstructure (replacing $\mathrm{Si}$ in tetrahedral positions), giving rise to products with a general formula established by Taylor in 1992 [57] and which also includes alkaline cations (Na and K) to offset the charge imbalance: $\left\{\left[\mathrm{Ca}_{4}\left(\mathrm{Si}_{5.5} \mathrm{Al}_{0.5} \mathrm{O}_{17} \mathrm{H}_{2}\right)\right] \mathrm{Ca}_{0.2} \cdot \mathrm{Na}_{0.1} \cdot 4 \mathrm{H}_{2} \mathrm{O}\right]$.

Figure 5: X-ray microdiffraction and SEM-secondary electron images of relict scoria (A and $B$ ) and cementitious matrix $(C$ and $D)$; sample collected from the foundation of Trajan's Market. Short dashes represent katoite; dots and dashes represent strätlingite, and long dashes represent åkermanite (modified from Jackson et al. 2014) [25].

\section{3.- Characterisation of Al-tobermorite and C-A-S-H in Roman concrete}

A new comprehensive characterisation of C-(A-)S-H using nanoscale soft X-ray spectroscopy at the $\mathrm{Ca} \mathrm{L}_{2,3-}$ and $\mathrm{Si} \mathrm{K}$-edges [32] provides new insights into the previously reported X-ray spectroscopy of Al-tobermorite and C-A-S-H collected from the ancient Roman concrete at Bainus Sinus [24]. The Ca L2,3-edge spectra of the C-(A)S-H and Al-tobermorite shown in Figure 6(a) are due to the excitation of $\mathrm{Ca}$ atoms from $2 \mathrm{p}^{6} 3 \mathrm{~d}^{0}$ to $2 \mathrm{p}^{5} 3 \mathrm{~d}^{1}$. Two major peaks, a2 and $\mathrm{b}_{2}$, were created due to the loss of degeneracy of $2 \mathrm{p}$ orbitals by spin-orbit coupling. The crystal field splitting generated minor peaks, $a_{1}$ and $b_{1}$, before each major peak, and the strength of the crystal field affects the energy separations (splitting energies, $\Delta \mathrm{L}_{3}=\mathrm{a}_{2}-\mathrm{a}_{1}$ and $\Delta \mathrm{L}_{2}=\mathrm{b}_{2}-\mathrm{b}_{1}$ ) in two doublets. The presence of a small leading peak a0, associated with the multipole interactions of core holes with valence electrons, coupled the effects of the 3D spinorbit splitting. 
The experimental results shown in Figure 6(a) indicate that, for all samples, Ca has a distorted octahedral-like coordination symmetry. The ratios between minor and major peaks are low, possibly indicating that - for all the $\mathrm{Ca} / \mathrm{Si}$ studied - there is no tendency to form well-crystallised phases, and that the interlayer $\mathrm{Ca}$ is six-fold, coordinated in a highly distorted octahedral symmetry. Therefore, the Ca L2,3-edge spectra of C-S-H can be modelled by a defective tobermorite $[28,53]$ where the low splitting energy at the edge is caused by the seven-fold coordinated Ca-O sheet in the intralayer of C-S-H, with minor contribution from the octahedral coordinated zeolitic $\mathrm{Ca}$ in the interlayer. For C-S-H with low $\mathrm{Ca} / \mathrm{Si}^{* 1}(0.6-1.2)$, the location of the major peaks ( $\mathrm{a}_{2}$ and $\mathrm{b}_{2}$ ) is constant, indicating that the same $\mathrm{Ca}$ oxidation and similar average coordination number of $\mathrm{Ca}-\mathrm{O}$. For $\mathrm{C}-\mathrm{S}-\mathrm{H}$ with high $\mathrm{Ca} / \mathrm{Si}$ (1.4 and 1.6); the position of the major peaks is $0.05-0.1 \mathrm{eV}$ lower than $\mathrm{C}-\mathrm{S}-\mathrm{H}$ with low $\mathrm{Ca} / \mathrm{Si}$. The peak positions for the synthetic C-A-S-H and C-S-H samples and for the Roman concrete Al-tobermorite and C-A-S-H are similar, indicating that the $\mathrm{Al}$ uptake $(\mathrm{Al} / \mathrm{Si}=0.05$ for the synthetic samples and $\mathrm{Al} / \mathrm{Si}=0.17$ for the Roman concrete) did not alter the coordination of $\mathrm{Ca}-\mathrm{O}$ complexes in their structures. Note that the major peaks for $\mathrm{C}-\mathrm{A}-\mathrm{S}-\mathrm{H}$ with $\mathrm{Ca} / \mathrm{Si}=1.4$ and 1.6 are located at slightly higher energies than for C-S-H.

Li et al. (2019) [32] proposed that this increase in energy is caused by the higher ordering of $\mathrm{CaO}_{7}$ as the $\mathrm{Al}$ incorporation leads to an elongation of the silicate chains and $\mathrm{CaO}_{7}$ sheets. The splitting energies observed in the spectra for C-A-S-H and C-S-H, ancient Roman C-A-S-H and Al-tobermorite are similar, indicating that the $\mathrm{Al}$ incorporation does not increase the coordination symmetry of the $\mathrm{Ca}-\mathrm{O}$ complexes for all samples studied. By comparing the spectra of $\mathrm{C}-\mathrm{A}-\mathrm{S}-\mathrm{H}$ with $\mathrm{C}_{2} \mathrm{AH}_{8}, \mathrm{C}_{4} \mathrm{ASH}_{12}$, $\mathrm{CAH}_{10}$ and ettringite to $\mathrm{C}-\mathrm{A}-\mathrm{S}-\mathrm{H}, \mathrm{Li}$ et al. (2019) [32] assigned the average coordination number of $\mathrm{Ca}$ in $\mathrm{C}-\mathrm{A}-\mathrm{S}-\mathrm{H}$ to slightly less than seven due to minor quantities of octahedral $\mathrm{Ca}$ in the interlayer; their conclusion holds for the Altobermorite and C-A-S-H obtained from the ancient Roman concrete. The lack of two clearly resolved peaks at the low-energy side of peak a indicates that AFm-like phases are not present in synthesised C-(A-)S-H nor in the ancient Roman C-A-S-H and Altobermorite [28-29].

\footnotetext{
${ }^{1} \mathrm{Ca} / \mathrm{Si}^{*}$ and $\mathrm{Al} / \mathrm{Si}^{*}$ are the initial bulk $\mathrm{Ca} / \mathrm{Si}$ and $\mathrm{Al} / \mathrm{Si}$ ratios, respectively
} 
The major peak a 1 of the Si K-edge peak occurs in the range of 1848.7-1849.7 eV, and it is assigned to the electronic transition from $1 \mathrm{~s}$ to antibonding $3 p$-like state in tetrahedrally symmetric $\mathrm{Si}$. The minor peaks a2 and a3 occur in the range of $\sim 1860-1867$ and $1853 \mathrm{eV}$, respectively, and they are assigned to a multi-scattering effect from more distant atom shells through photoelectron interaction. The $\mathrm{Si}-\mathrm{O}$ bond length and the degree of silicate polymerisation have a marked influence on the energy value of the major peak a while the interatomic distance has a major influence on the energy value of the minor peak a2. As shown in Figure 6(b), the (a) the Si K-edges gradually shift to lower energy as the $\mathrm{Ca} / \mathrm{Si}$ ratio increases, which is caused by an increase in the electron shielding and a reduction in the effective $\mathrm{Si}-\mathrm{O}$ bond; and (b) the major peak $\mathrm{a}_{1}$ sharpens with decreasing $\mathrm{Ca} / \mathrm{Si}$ ratios due to increasing long-range ordering of silicate tetrahedra. As the $\mathrm{Ca} / \mathrm{Si}$ ratio increases, the energy of the $\mathrm{Si}$ K-edges for C-A-S-H are higher than C-S-H because of the increase polymerisation in the aluminosilicate chains. The energy positions of Roman concrete were measured [24] in a beamline still under commission, so there is a possibility of having shifts in the energy calibration. Based on recent measurements of the $\mathrm{Si} \mathrm{K}$-edge of triclinic $\mathrm{C}_{3} \mathrm{~S}$ using the same beamline that now is fully stable, it was possible to determine the shift more precisely; the corrected Si Kedge for the Al-tobermorite and C-A-S-H obtained from Roman concrete are given in Figure 6(b). The results compare well with the values of the synthetic C-A-S-H; however, more experiments are necessary to compare the small variations in the peaks.

Jackson et al. (2013) [24] measured the mechanical properties of the Al-tobermorite collected in a relict lime clast of the Baianus Sinus concrete breakwater and obtained an isothermal bulk modulus of $55 \pm 5 \mathrm{GPa}$. It is insightful to compare this result to the recent comprehensive experiments of the mechanical properties of nano-crystalline C-S$\mathrm{H}$ and C-A-S-H [28-29]. Geng et al. [29] integrated high-pressure X-ray diffraction experiments with atomistic simulations to correlate the mechanical properties of nanocrystalline C-S-H to the systematically varying molecular structure of C-S-H caused by changing the $\mathrm{Ca} / \mathrm{Si}$ ratio. Contrary to the defect-driven hypothesis, they showed that the stiffness of C-S-H increases with increasing $\mathrm{Ca} / \mathrm{Si}$ in the range $0.8 \leq \mathrm{Ca} / \mathrm{Si} \leq 1.3$ despite an increase in the omission sites in the silica chains. It was shown that the increase in stiffness correlates directly to the densification of the interlayer spacing rather than the contraction of intralayer $\mathrm{Si}-\mathrm{O}$ and $\mathrm{Ca}-\mathrm{O}$ bonds; therefore, the results validate the hypothesis that the nano-mechanical properties of C-S-H are predominantly density- 
driven. In a parallel paper, Geng et al. [28] studied the mechanical properties of C-A-S$\mathrm{H}$ and demonstrated that (a) the ab-planar stiffness is independent of the vacancies in bridging tetrahedra sites and $\mathrm{Al}$ for Si substitution; (b) the decrease in spacing and/or increase of interlayer water and $\mathrm{Ca}^{2+}$ stiffens the soft $c$-axis of non-cross-linked C-(A)S-H; and (c) the dreierketten chain cross-links behave as stiff springs that increase the values of the mechanical properties of $\mathrm{C}-(\mathrm{A}-) \mathrm{S}-\mathrm{H}$. The obtained bulk moduli for the synthetic C-A-S-H were $50 \pm 2,64 \pm 3$, and $71 \pm 3 \mathrm{GPa}$ for $(\mathrm{Al} / \mathrm{Si})=0.0,0.05,0.1$, respectively [28]. Compared to the synthetic C-A-S-H, the Al-tobermorite with a high $(\mathrm{Al} / \mathrm{Si})=0.17$ has a lower than expected bulk modulus; therefore, it is desirable to collect and measure the bulk modulus of Al-tobermorite from different sites to study if there is a trend.

Figure 6: (a) Ca L2,3-edge and (b) Si K-edge XANES spectra of Al-tobermorite, C-A-S$H$ from ancient Roman concrete (data from Jackson et al. 2013) [24], C-S-H (solid lines) compared to $C-A-S-H$ with $A l / S i *=0.05$ (dashed lines) after 182 days of hydration at $20{ }^{\circ} \mathrm{C}$ (after Li et al. 2019 [32]). Ca/Si* and $\mathrm{Al} / \mathrm{Si}{ }^{*}$ are the initial bulk Ca/Si and $\mathrm{Al} / \mathrm{Si}$ ratios, respectively.

\section{3.- COMPARISON BETWEEN MODERN HYBRID AND ROMAN CEMENTS}

Modern Hybrid Cements consist in a combination of materials that when hydrated generate a series of products with variable chemistries and microstructures. Given their technological features and potential for sustainability, blends of Portland and Alkaline cements are most prominent among a wide spectrum of hybrid cements [9-11].

The merger of existing knowledge of the basics of portland and alkaline cement chemistry has spawned the development of hybrid alkaline cements. Research in the area was pioneered by some of the present authors, who published their first paper on the subject in 2007 [58]. The industrial-scale testing of hybrid cements now underway is the result of the progress made in the interim, much of which may be attributed to the understanding gained by NMR analysis. Nonetheless, the role in that progress of other analytical techniques besides NMR such as SEM, TEM, FTIR and similar should not be overlooked. Moreover, their joint use has shown that they are inter-complementary and deliver compatible and consistent information [9-15]. 
The hydration products precipitated in these cements are a mix of gels, governed primarily by the type and concentration of the alkalis used and the chemical composition of the precursors [9-15]. In blends containing $30 \%$ OPC clinker and $70 \%$ fly ash (type F), for instance, the product is a C-S-H gel containing aluminium and alkalis that yields a $(\mathrm{C}, \mathrm{N})-\mathrm{A}-\mathrm{S}-\mathrm{H}-\mathrm{like}$ gel, and a N-A-S-H gel bearing calcium that gives rise to $(\mathrm{N}-(\mathrm{C})-\mathrm{A}-\mathrm{S}-\mathrm{H}[9-15,58-63]$.

Synthetic gels [12-13] and samples prepared with low clinker and high type F ash, or a good natural pozzolan or some BSF content $[10,11,58-63]$ have been deployed in gel compatibility studies of these complex systems. Their composition and micro- and nanostructural characteristics are highly reminiscent of the Al-tobermorite and C-A-S-H products found in the Roman concretes described above [4-6]

The type of supplementary cementitious material (SCM) used in the industrial-scale manufacture of industrial hybrid cements determines their chemical composition, which may differ from one SCM to another. The significant microstructural changes induced by 'alkaline activators' (which may be any alkaline hydroxide or salt such as $\mathrm{NaOH}$, $\mathrm{Na}_{2} \mathrm{CO}_{3}, \mathrm{Na}_{2} \mathrm{SO}_{4}$ or $\left.\mathrm{NaCl}[9-11,60]\right)$ in the gel or gels formed, in turn, have been found to be closely related to mechanical strength development.

Essentially two types of gels form in hybrid systems: a) C-S-H gel ensuing from clinker hydration that takes aluminium up in its structure $\rightarrow$ C-(A)-S-H $[12,64,65]$; and b) a gel in which the composition varies with the precursor. In FA hybrids, i.e., silica- and alumina-high systems, that second compound is a N-A-S-H gel bearing $\mathrm{Ca} \rightarrow$ (N,C)-A-S-H [59,60]; whereas in Ca-rich systems, i.e., BS hybrids, the main reaction product is a C-A-S-H-like gel [66-69].

Based on NMR, supplemented by XRD, FTIR, BSEM and TEM data, Garcia-Lodeiro et al. [60] proposed a nanostructural model for gel formation in hybrid alkaline cement, the stages of which are summarised below.

The first step consists in the dissolution of the silico- and calcium silicates in the alkaline solution and the release of a variety of dissolved species that ultimately saturate the medium but that are not distributed uniformly. As the locally concentrated ions reach saturation, there is the development of competitive reactions in which $\mathrm{C}-\mathrm{S}-\mathrm{H}$ and 
N-A-S-H gels precipitate simultaneously. As a result the silicon concentration rises in the reaction medium, and consequently silicon is taken up in both gels [12-13].

In parallel, the $\mathrm{Ca}^{2+}$ and $\mathrm{Al}^{3+}$ ions in the aqueous solution begin to diffuse through the hardened cementitious matrix. The fairly small number of $\mathrm{Ca}^{2+}$ ions not taken up in the C-S-H gel form an (N,C)-A-S-H gel by interacting with the N-A-S-H gel [13,60,69-70]. The ion exchange involved in the replacement of sodium with calcium, species with similar ionic radii and electronegative potential values, is reminiscent of the mechanism observed in clay and zeolites, where the three-dimensional structure of the (N,C)-A-S$\mathrm{H}$ gel is conserved. Similarly, the aluminium taken up into the composition of C-S-H gel, preferably in bridging sites, yields $\mathrm{C}-(\mathrm{A})-\mathrm{S}-\mathrm{H}$ and subsequently $\mathrm{C}-\mathrm{A}-\mathrm{S}-\mathrm{H}$ gels as the aluminium content rises [12,70-71].

Calcium continues to diffuse through the pores of the matrix and interact with the $(\mathrm{N}, \mathrm{C})-\mathrm{A}-\mathrm{S}-\mathrm{H}$ gel $[13,60$ 70-71]. The Si-O-Al bonds are distorted by the polarising effect of the $\mathrm{Ca}^{2+}$ in the formation of Si-O-Ca bonds, the outcome of which is stress and ultimately rupture. The ions in the gels generated in such cementitious systems may be exchanged by one of two possible mechanisms [11-13,60]: The release of aluminium from the N-A-S-H gel translates into the formation of less polymerised C-A-S-H gels. More N-A-S-H gel may form, however, for the alkalis released in the pore solution may also react with unreacted precursor, and the new gel may in turn react with C-S-H gel. Over time, alkalis are taken up into the structure of the reaction products, lowering the alkaline concentration until the pore solution reaches equilibrium.

To confirm the long-term validity of these hypotheses and the prevalence, over time and given equilibrium conditions (reached in the long term), of (N)-C-A-S-H gel, Palomo and Fernandez are presently studying these systems in samples over 3 years old. The evidence collected to date indicates that (N)-C-A-S-H may be essentially the same product (C-A-S-H or Al-tobermorite) as found by Jackson et al. in the concrete in Roman marine structures built 2000 years ago [4-6]. Al-Tobermorite, actually, might be the result of a slow crystallisation process of some former cementitious gels (2000 years of gradual changes leading to the thermodynamic stability).

The products formed in these complex cementitious blends and their proportions vary with reaction conditions such as the chemical composition, shape, mineralogy and 
particle size distribution of the prime materials (the smaller the particle size in precursor, the higher its reactivity), along with the activator-generated alkalinity $(\mathrm{pH})$ [60].

\section{1.- Coincident chemical and mineral compositions in hybrid and Roman cements}

The first factor to be stressed here is the chemical and mineral similarity between the raw materials used by the Romans to manufacture their cements and those used by the authors of this paper to prepare modern hybrid cements. The Romans used a fraction of lime and the authors a fraction of portland clinker, both of which generate considerable amounts of $\mathrm{Ca}(\mathrm{OH})_{2}$ when hydrated. The volcanic ash (or other natural pozzolans) used by the Romans and the fly ash from coal combustion (or a range of other pozzolans) employed by the authors have a highly reactive vitreous component and 'similar' amounts of the oxides needed to form cementitious gels (silica, alumina and calcium oxide). Table 1 compares the chemistry of Compostilla fly ash, the Spanish type F fly ash used in this study, to the chemical composition of 12 types of volcanic ash analysed by Djobo et al. [72]. The data show that the two materials are wholly comparable, chemically speaking. The most prominent feature of the mineral composition of fly ash from steam power plants is that it may exhibit a sizeable ( $>60 \%)$ vitreous fraction, with the same reactivity as found in volcanic ash $[9-11,72]$.

Table 1. Comparison of the XRF-determined chemical composition (\%wt) of fly ash (FA) (PHILIPS PW-1004 X-ray spectrometer) and 12 types of volcanic ash (VS) [72].

\begin{tabular}{c|c|c|c|c|c|c|c|c|c|c|c}
\hline & $\mathrm{SiO}_{2}$ & $\mathbf{A l}_{\mathbf{2}} \mathbf{O}_{\mathbf{3}}$ & $\mathbf{F e}_{\mathbf{2}} \mathbf{O}_{\mathbf{3}}$ & $\mathbf{C a O}$ & $\mathbf{M g O}$ & $\mathbf{S O}_{\mathbf{3}}$ & $\mathbf{N a}_{\mathbf{2}} \mathbf{O}$ & $\mathbf{K}_{\mathbf{2}} \mathbf{O}$ & $\mathbf{T i O}_{\mathbf{2}}$ & Other & $\mathbf{L o I}$ \\
\hline FA & 40.48 & 22.08 & 8.36 & 4.32 & 1.65 & 3.29 & 1.06 & 3.56 & 1.03 & 2.37 & 11.80 \\
\hline VS & $40-70$ & $11-20$ & $1-15$ & $1-10$ & $0,2-10$ & $0-0,1$ & $0,1-6$ & $0-4$ & $0-3$ & --- & $0-10$ \\
\hline
\end{tabular}

In short, both volcanic and steam power plant ash are pozzolanic, which means that they can fix lime even when submerged in seawater.

In addition, in hybrid cements alkalis are included with the other raw materials in the form of alkaline salts, whilst Roman cements located in coastal areas take up alkaline salts present in seawater. In light of the foregoing, prior to hydration the two chemical systems can be said to be very similar (Figure 7). 
After hydration begins, the chemical species dissolved in the hydration medium in Roman and hybrid cements are essentially the same and their concentrations likewise the same. Be it said in this context that no two portland cements are identical, nor are any two types of fly ash or two natural pozzolans identical, although certain chemical scenarios prevail and tend (thermodynamically) to stabilise mineral forms with specific properties. Those scenarios underlie production the world over of what are contended to be universal binders (although manufactured with different local materials) because they are conceptually identical in their chemistry and mineralogy.

Lime and clinker are the primary sources of $\mathrm{CaO}$ and pozzolans of $\mathrm{SiO}_{2}$ and $\mathrm{Al}_{2} \mathrm{O}_{3}$ (although silica and alumina are also present in clinker), whilst the alkalis are either drawn from seawater or included in the raw mix.

The analytical tools used by the scientific community to study Roman and hybrid cements (sophisticated tools in the research described here) guide the interpretation of the findings for the two in a single direction. The hardened matrices comprise a number of cementitious gels and/or zeolitic crystalline phases (the relatively high crystalline phase content in the Roman cements should come as no surprise, given the 2000-plus years lapsing since they were hydrated). The gels (some of them containing alkalis in their structure), are members of the families normally found in blended and alkaline cements (Figure 7).

Figure 7: (a) $\mathrm{CaO}-\mathrm{Al}_{2} \mathrm{O}_{3}-\mathrm{SiO}_{2}$ ternary diagram of cementitious materials according to refs [9,10,72-75], (B) Pseudo-ternary $\mathrm{CaO}-\mathrm{Al}_{2} \mathrm{O}_{3}-\mathrm{SiO}_{2}$ system (neglecting $\mathrm{Na}_{2} \mathrm{O}$ content) showing compositional range of cementitious gels according to refs [10$13,24,62,74,77.78]$.

\section{2.- Laboratory preparation of a hybrid cement simulating the formula found in a}

\section{Roman cement}

A cementitious material consisting in a blend of fly ash (from a steam power plant at Compostilla, Spain) and commercial lime was prepared in the laboratory to reproduce Roman cements of the type described in ancient marine structures. That material was then used to explore the hypothetical conceptual identity between modern hybrid and 
Roman cements in greater depth [75]. The ash was ground in a ball grinder for $4 \mathrm{~h}$ to induce optimal reactivity, whilst the lime was heated at $800{ }^{\circ} \mathrm{C}$ for $4 \mathrm{~h}$ prior to use to ensure it consisted in anhydrous $\mathrm{CaO}$. One hundred per cent of the blend comprised particles smaller than $45 \mu \mathrm{m}$. The blend prepared, containing $80 \%$ ash $+20 \% \mathrm{CaO}$, was homogenised by milling the components together for $15 \mathrm{~min}$ in a laboratory ball grinder with a capacity of $1 \mathrm{~kg}$.

Equations 1, 2 and 3 describe the chemical and mineral developments that may take place between pozzolan and lime and which may generate products similar to those obtained in portland cement hydration $[57,79-80]$ as well as those identified in the Roman cements prepared 2000 years ago. The pozzolan contains both silica that reacts with calcium hydroxide to form C-S-H gel (Equation 1) and $\left(\mathrm{Al}(\mathrm{OH})_{4}\right)^{-}$that reacts with calcium hydroxide and water to form calcium aluminate hydrates such as $\mathrm{C}_{4} \mathrm{AH}_{13}$, $\mathrm{C}_{3} \mathrm{AH}_{6}$ or hydrogarnet (Equation 2). In combination with silica, it may also give rise to $\mathrm{C}_{2} \mathrm{ASH}_{8}$ or strätlingite (Equation 3) or to $\mathrm{AFm}$ and/or $\mathrm{AFt}$ in the presence of anions such as sulfates, carbonates or chlorides (Equation 4).

$$
\begin{aligned}
& \mathrm{xCa}(\mathrm{OH})_{2}+\mathrm{nSiO}_{2}+\mathrm{zH}_{2} \mathrm{O} \rightarrow \text { Gel C-S-H (Eq. 1) } \\
& \mathrm{xCa}(\mathrm{OH})+\mathrm{mAl}_{2} \mathrm{O}_{3}+\mathrm{zH}_{2} \mathrm{O} \rightarrow \text { Calcium aluminate hydrates such as } \mathrm{C}_{4} \mathrm{AH}_{13}, \mathrm{C}_{3} \mathrm{AH}_{6} \text { (Eq. 2) } \\
& \mathrm{xCa}(\mathrm{OH})_{2}+\mathrm{nSiO}_{2} \mathrm{mAl}_{2} \mathrm{O}_{3}+\mathrm{zH}_{2} \mathrm{O} \rightarrow \mathrm{Gel} \mathrm{C}-(\mathrm{A})-\mathrm{S}-\mathrm{H}, \mathrm{C}_{2} \mathrm{ASH}_{8} \text { (strätlingite) (Eq. 3) } \\
& \mathrm{xCa}(\mathrm{OH})_{2}+\mathrm{n}\left[\left(\mathrm{SO}_{4}\right)^{2-}\right]+\mathrm{m}\left[\mathrm{Al}(\mathrm{OH})_{4}^{-}\right]+\mathrm{z} \mathrm{H}_{2} \mathrm{O} \rightarrow 3 \mathrm{CaO} \cdot \mathrm{Al}_{2} \mathrm{O}_{3} \cdot 3 \mathrm{CaSO}_{4} \cdot 32 \mathrm{H}_{2} \mathrm{O} \text { (ettringite) ((Eq. 4) }
\end{aligned}
$$

In this specific experience focused to reproduce a Roman cement, a binder was prepared by blending $80 \%$ fly ash with $20 \% \mathrm{CaO}$ and then hydrated with seawater (ASTM D 1141). A water/binder ratio of 0.36 was utilised (ratio needed for good workability as per the mini-slump test). The pastes were moulded into $1 \times 1 \times 6 \mathrm{~cm}$ specimens and cured in a curing chamber at $22{ }^{\circ} \mathrm{C}$ and $\mathrm{RH}>90 \%$ for $6 \mathrm{~d}$. The demoulded specimens were then cured either in the laboratory air or in seawater, which was replenished after $7 \mathrm{~d}$, $14 \mathrm{~d}, 28 \mathrm{~d}, 90 \mathrm{~d}$ and $180 \mathrm{~d}$. The $14 \mathrm{~d}, 28 \mathrm{~d}$ and $180 \mathrm{~d}$ specimens were tested to failure (further specimens were stored for later age testing). The hydration reaction was 
detained in the broken specimens by immersion in acetone, after which the pastes were XRD, BSEM and NMR-analysed.

The $14 \mathrm{~d}, 28 \mathrm{~d}$ and $180 \mathrm{~d}$ compressive and flexural strength values for the air- and seawater-cured pastes are given in Table 2. Early age development was found to be fairly low compared to today's cements. Nonetheless, the values rose substantially with hydration time, particularly in the pastes cured in seawater.

Table 2.- Compressive strength of ( $80 \%$ fly ash $+20 \% \mathrm{CaO})$ pastes hydrated with seawater and cured in air or in seawater.

\begin{tabular}{l|l|l|l|l|l|l}
\hline \multirow{2}{*}{ L/S ratio=0.36 } & \multicolumn{3}{|c|}{ Air-cured } & \multicolumn{3}{c}{ Seawater-cured } \\
\cline { 2 - 7 } & 14 days & 28 days & 180 days & 14 days & 28 days & 180 days \\
\hline Flexural (MPa) & $4.1 \pm 0.7$ & $3.3 \pm 0.4$ & $5.0 \pm 0.2$ & $3.4 \pm 0.7$ & $4.6 \pm 0.4$ & $6.1 \pm 1.1$ \\
\hline $\begin{array}{l}\text { Compressive } \\
(\mathrm{MPa})\end{array}$ & $14.1 \pm 1.7$ & $13.5 \pm 2.8$ & $14.5 \pm 2.5$ & $10.8 \pm 1.4$ & $14.3 \pm 0.9$ & $31.0 \pm 4.5$ \\
\hline
\end{tabular}

The XRD pattern, BSEM micrograph and microanalysis for paste first hydrated with and then soaked in seawater for 180 days are reproduced in Figure 8. The hump on the diffractogram ranging across $2 \theta$ values of $25^{\circ}$ to $35^{\circ}$ was associated in part with unreacted ash and in part with amorphous cementitious gels, the presence of which was confirmed by the BSEM findings (Figure $8(\mathrm{~b})$ and (c)). Signals were also identified for crystalline ettringite and likewise crystalline calcium aluminium hydrates, one of which contained chlorine, logically sourced from the seawater. The same phases were identified in the BSEM analysis (Figure 8(b) and (c)). The inference of all the foregoing is that irrespective of whether the hybrid cement was prepared with a low fraction of lime or portland clinker, when hydrated it consistently generated a very similar suite of reaction products. The cementitious gels identified in this material varied somewhat depending on the area of the sample analysed: aluminium- and silicon-high gels were found around unreacted ash particles or the voids left by them (Figure 8(b), point 1), whereas gels with a higher calcium content formed around lime particles or where they were once present (Figure 8(b), point 2). The former may be associated with an (N,C)A-S-H-like gel and the latter with C-(A)-S-H-like gels. The sodium and magnesium taken up into the gel structure were sourced from the seawater used in the experiment. All these gels were very similar to the ones observed in the alkaline activation of slag 
[66-69], a number of hybrid cements [62,74], and the Roman cements described in section 2 of this article.

Figure 9 shows the ${ }^{27} \mathrm{Al},{ }^{29} \mathrm{Si}$ and ${ }^{23} \mathrm{Na}$ NMR-MAS spectra for the same pastes submerged in seawater for $28 \mathrm{~d}$ or $180 \mathrm{~d}$. The ${ }^{27} \mathrm{Al}$ NMR spectra for the pastes revealed the presence of tetrahedrally and octahedrally coordinated aluminium. Part of the $\mathrm{Al}(\mathrm{IV})$ signal may have been due to the $\mathrm{Al}_{\mathrm{T}}$ in the starting ash, which nonetheless shifted slightly from $+50 \mathrm{ppm}$ to $+56 \mathrm{ppm}$ in the hydrated material. This shift suggests that part of the aluminium in the cementitious matrix had reacted, generating an $\mathrm{Al}_{\mathrm{T}}$ signal attributed to $\mathrm{Q}^{4}(4 \mathrm{Si})$ units, which is usually associated with the $\mathrm{Al}_{\mathrm{T}}$ in $(\mathrm{N}, \mathrm{C})-\mathrm{A}-\mathrm{S}$ $\mathrm{H}$ gel [9-13]. The $\mathrm{Al}(\mathrm{VI})$ signals, in turn, exhibited a peak at $+13 \mathrm{ppm}$ associated with the aluminium in ettringite $[\mathbf{8 1 - 8 3}]$ and a signal around $+9 \mathrm{ppm}$, associated with the overlapping of signals generated by crystalline calcium aluminate hydrates [81-83]. The presence of these phases was corroborated by XRD analysis and their formation is in keeping with Equations 2 and 4. In this case the sulfates were sourced from the seawater used for mixing, although since the dissemination of sulfates in the medium where the material was submerged could not be ruled out, the mechanism might be envisaged as the sequence of two consecutive reactions (Equations 5 and 6).

Figure 8. (a) Diffractogram for paste hydrated with and subsequently soaked for 180 days in seawater; (b) and (c) BSEM micrographs and microanalysis for the same material.

$$
\mathrm{Ca}(\mathrm{OH})_{2}+\mathrm{Na}_{2} \mathrm{SO}_{4}+2 \mathrm{H}_{2} \mathrm{O} \rightarrow \mathrm{CaSO}_{4} \cdot 2 \mathrm{H}_{2} \mathrm{O}+2 \mathrm{NaOH} \quad \text { (Eq. 5) }
$$

$\mathrm{CaSO}_{4} \cdot 2 \mathrm{H}_{2} \mathrm{O}+\left[\mathrm{Al}(\mathrm{OH})_{4}\right]^{-}($from $\mathrm{FA})+\mathrm{H}_{2} \mathrm{O} \rightarrow 3 \mathrm{CaO} \cdot \mathrm{Al}_{2} \mathrm{O}_{3} \cdot 3 \mathrm{CaSO}_{4} \cdot 32 \mathrm{H}_{2} \mathrm{O}$

The formation of $\mathrm{NaOH}$ as one of the products (Equation 5) merits particular note, for it raised $\mathrm{pH}$ locally. That triggered a reaction similar to the one described for hybrid alkaline cements prepared with neutral alkaline $\left(\mathrm{Na}_{2} \mathrm{SO}_{4}, \mathrm{Na}_{2} \mathrm{CO}_{3}, \mathrm{~K}_{2} \mathrm{CO}_{3}\right.$, etc) salts as activators which, when reacting with portlandite, generate in situ $\mathrm{NaOH}$ (Equation 5) $[60]$.

Gypsum promotes ettringite formation (see Equation 6) and consequently a denser, higher early age strength matrix [9-11]. In situ $\mathrm{NaOH}$ formation and the concomitant rise in local $\mathrm{pH}$ favour the dissolution of the aluminosilicates in the fly ash (in this 
specific case), in turn followed by alkali-activated aluminosilicate (geopolymer) formation [60].

The ${ }^{29} \mathrm{Si}$ NMR spectra for the simulated Roman cements shown in Figure 9(b) exhibited a series of peaks that concurred with those observed for the hybrid cements essentially associated with the formation of a mix of C,N-A-S-H and C-S-A-H gels [12-13,68-69]. Assignment of the signal at $-86 \mathrm{ppm}$ that intensified substantially after 180 days is no easy matter due to possible signal overlapping. It might have been generated by strätlingite formation [84], (although the 18 day XRD analysis failed to detect this phase), for instance, or by highly polymerised units $\left[\mathrm{Q}^{3}(3 \mathrm{Al})\right.$ or even $\left.\mathrm{Q}^{4}(4 \mathrm{Al})\right]$ in $\mathrm{C}-\mathrm{A}$ S-H or (N,C)-A-S-H -like gels [66-64,68,69]. The signals appearing at more negative values (-93 ppm, -98 ppm, -101 ppm and -105 ppm) suggested the presence of $\mathrm{Q}^{4}(\mathrm{mAl})$ or $\mathrm{Q}^{3}(\mathrm{mAl})$ in $(\mathrm{N}, \mathrm{C})-\mathrm{A}-\mathrm{S}-\mathrm{H}-\mathrm{like}$ gels. Such gels are characterised by two-dimensional (C-A-S-H or (N)-C-A-S-H gels) or three-dimensional (N-A-S-H or (N,C)-A-S-H gels) structures in which the alkalis appear to play an important role in balancing the charge deficit created when aluminium replaces silicon in the structure. In alkaline or hybrid cements the alkalis are sourced from the alkaline activator used; in Roman concretes, or at least in those used in marine structures, the alkalis were found to form part of different mineral phases, including zeolites and cementitious phases [4-6], although to date no conceptual identity had ever been established between the phases found in Roman and those developing in hybrid cements.

${ }^{23} \mathrm{Na}$ NMR spectra were also recorded in this study to confirm that $\mathrm{Na}$ (the sodium present in the salts dissolved in seawater) was taken up into the cementitious gels. The ${ }^{23} \mathrm{Na}$ spectra for both the $28 \mathrm{~d}$ and $180 \mathrm{~d}$ pastes reproduced in Figure 9(c) contained a signal confirming the presence of $\mathrm{Na}$. Centred over $-4 \mathrm{ppm}$ and $-6 \mathrm{ppm}$, that signal was associated with the presence of partially hydrated sodium needed to restore the charge balance altered in alkaline cements (geopolymers) when silicon is replaced by aluminium in the structure of aluminosilicate hydrates, in all likelihood (N,C)-A-S-H gels [12-13, 59, 68-69]. BSEM analysis also detected the presence of sodium in the cementitious gels (Figure 8).

Fly ash pozzolanicity is enhanced by the portlandite in these binders [79-80], whilst its reactivity is boosted by the alkaline activators [58-60]. Under such conditions cement 
matrices may contain C-(A)-S-H-like, C-A-S-H-like and (N,C)-A-S-H-like gels [58-60, 66-69]. The chemical interaction among those products results in the formation of a final (N,C)-A-S-H gel very similar to the Al-tobermorite observed by Jackson et al. [46] in Roman concretes, except for the degree of crystallinity stimulated by the pass of time. The gels precipitating are not pure but shown to contain dissolved species. Secondary products may also form, consisting in solid solutions of hydrotalcite-like minerals $\left[\mathrm{Mg}_{6} \mathrm{Al}_{2} \mathrm{CO}_{3}(\mathrm{OH})_{16} \times 4 \mathrm{H}_{2} \mathrm{O}\right]$; calcium aluminate hydrates $\left(\mathrm{C}_{4} \mathrm{AH}_{13}\right.$ and others); hydrogarnets $\left[\mathrm{C}_{3} \mathrm{ASS}_{3}-\mathrm{nHn}\right.$ and $\left.\mathrm{C}_{6} \mathrm{AFS}_{2} \mathrm{H}_{8}\right]$; strätlingite $\left[\mathrm{C}_{2} \mathrm{ASH} \mathrm{H}_{8}\right]$; ettringite, and an occasional carboaluminate $\left[\mathrm{C}_{3} \mathrm{~A} \cdot \mathrm{CaCO}_{3} \mathrm{H}_{11}\right]$.

Figure 9. (a) ${ }^{27} \mathrm{Al}$. (b) ${ }^{29} \mathrm{Si}$ and (c) ${ }^{23} \mathrm{Na}$ MAS NMR spectra for seawater-hydrated $28 \mathrm{~d}$ and $180 \mathrm{~d}$ seawater-cured $80 \% \mathrm{FA}+20 \% \mathrm{CaO}$ (Bruker Avance-400 spectrometer conditions: ${ }^{27} \mathrm{Al}, 104.3 \mathrm{MHz} ; v_{R}=10 \mathrm{kHz} ; 200$ acquisitions; reference, $\mathrm{Al}\left(\mathrm{H}_{2} \mathrm{O}\right) \sigma^{3+} ;{ }^{29} \mathrm{Si}$, $79.5 \mathrm{MHz} ; v_{R}=10 \mathrm{kHz} ; 1000$ acquisitions; reference, $\mathrm{TMS} ;{ }^{23} \mathrm{Na}, 105.8 \mathrm{MHz} ; v_{R}=10$ $\mathrm{kHz}$; 160; acquisitions; reference aqueous solution of $\mathrm{NaCl}$ ).

\section{5.- MODERN HYBRID CEMENT INDUSTRIALISATION}

Just as proving one of the primary starting hypotheses of this study, i.e., that some Roman cements generated the same reaction products as portland-alkaline hybrid cements, constituted a substantial scientific challenge, proving the industrial viability of the latter constitutes a sizeable technological challenge in the context of the sustainability issues surrounding portland cement manufacture.

In 2009 cement manufacturers working out of Slovakia (Považská cementáreň, a.s., Ladce) decided to assume both the technological and the environmental challenges. In 2012 they patented a product named H-Cement in Slovakia [85]. Their product consists essentially in a blend of materials containing $20 \%$ portland clinker and $80 \%$ alkaline cement, in turn a combination of fly ash, blast furnace slag and alkaline sulfates. Microstructural data have been reported for hybrid cements similar to H-Cement in recent years [9-11].

The trial runs to produce H-Cement on an industrial scale began in 2011 in an industrial mill fitted with a high performance sorter where Považská cementáreň normally produce an EN 197-1-compliant CEM I 52.5 R cement. Industrially produced HCement (Hybrid Cement) was found to be readily millable to a specific surface of 
$6100 \mathrm{~cm}^{2} / \mathrm{g}$. It was further characterised by an output of $22 \mathrm{t} / \mathrm{h}$ and an energy consumption of $63 \mathrm{kWh} / \mathrm{t}$, compared to an output of $12 \mathrm{t} / \mathrm{h}$ and energy consumption of $115 \mathrm{kWh} / \mathrm{t}$ for conventional CEM I $52.5 \mathrm{R}$ cement with a specific surface of $5100 \mathrm{~cm}^{2} / \mathrm{g}$ produced in the same facility. From 2011 to 2012 several hundred tonnes of H-Cement were manufactured at Ladce, Slovakia, monitoring the quality to the procedures described in standard EN 197. That identified a need to revise or rewrite the European standard to improve the technical assessment of materials which, like $\mathrm{H}$-Cement or some Roman cements, lie barely within or even outside the compositional limits specified (Pantheon at Rome, built in 125 AC with no Clinker Portland, could not be included within the standards of today). Based on their own experience, Považská cementáreň wrote up an in-house specifications sheet for H-Cement further to the quality criteria set out in standard ISO 9001. The first concretes made with H-Cement were mixed and tested at the Považská cementáreň facility as well as in outside laboratories.

\section{1.- Properties of $\mathrm{H}-\mathrm{Cement}$}

The most significant differences between the mineral compositions of H-Cement and portland cement are listed in Table 3. Most of the crystalline phases in both materials were sourced from the portland clinker, which accounted for just $20 \%$ of the $\mathrm{H}$ Cement. Table 3 also shows that H-Cement had a greater specific surface and higher density than OPC. All these differences obviously impacted the water reactivity of the two materials. Mechanical strength developed earlier in OPC than in H-Cement (both manufactured in the same facility, Table 3). Nonetheless, the $28 \mathrm{~d} \mathrm{H}$-Cement exhibited compressive strength of around $40 \mathrm{MPa}$, which is more than sufficient to meet today's engineering requirements. Another significant finding was that water demand (in mortars) was lower in H-Cement than in OPC. In other words, a certain natural plasticity was observed in H-Cement that translated into a lower water demand for a given consistency (a feature with high added value in terms of sustainability). 
Table 3. Fundamental properties of H-Cement and OPC

\begin{tabular}{l|c|c|c|c|c|c|c|c|c|c}
\hline \multicolumn{10}{c}{ Mineral composition of H-cement (HC) and OPC (\%wt) } \\
\hline & $\mathbf{C}_{\mathbf{3}} \mathbf{S}$ & $\mathbf{C}_{\mathbf{2}} \mathbf{S}$ & $\mathbf{C}_{\mathbf{3}} \mathbf{A c}$ & $\mathbf{C}_{\mathbf{4}} \mathbf{A F}$ & $\mathbf{C}_{\text {free }}$ & Mullite & Quartz & $\mathbf{K}_{\mathbf{2}} \mathbf{S O}_{\mathbf{4}}$ & Portlandite $\mathbf{C a S O}_{\mathbf{4}}$ \\
\hline $\mathbf{H C}$ & 13.28 & 2.49 & 0.64 & 1.59 & 0.30 & 0.07 & 0.02 & 0.20 & 0.11 & - \\
\hline OPC & 61.50 & 10.3 & 0.65 & 10.71 & 0.26 & 0.35 & 0.28 & 1.63 & 1.23 & 8.66 \\
\hline
\end{tabular}

Physical properties

\begin{tabular}{|c|c|c|c|c|c|c|c|c|}
\hline & \multicolumn{2}{|c|}{$\begin{array}{c}\text { Specific surface } \\
\left(\mathrm{m}^{2} / \mathrm{kg}\right)\end{array}$} & \multicolumn{2}{|c|}{$\begin{array}{c}\text { Water demand } \\
\text { (\% wt.) }\end{array}$} & \multicolumn{2}{|c|}{$\begin{array}{c}\begin{array}{c}\text { Setting time } \\
(\mathrm{min})\end{array} \\
\end{array}$} & \multicolumn{2}{|c|}{ Volume stability (mm) } \\
\hline $\mathrm{HC}$ & \multicolumn{2}{|c|}{696.8} & \multicolumn{2}{|r|}{33.0} & \multicolumn{2}{|r|}{$230 / 285$} & \multicolumn{2}{|r|}{0.5} \\
\hline OPC & \multicolumn{2}{|c|}{344.7} & \multicolumn{2}{|r|}{25.4} & \multicolumn{2}{|r|}{$220 / 285$} & \multicolumn{2}{|r|}{0.0} \\
\hline \multicolumn{9}{|c|}{ Physical-mechanical properties in mortars } \\
\hline & \multirow[t]{2}{*}{$\begin{array}{c}\text { W/c } \\
\text { Ratio }\end{array}$} & \multirow[t]{2}{*}{$\begin{array}{c}\text { Consist. } \\
(\mathrm{mm})\end{array}$} & \multirow{2}{*}{$\begin{array}{c}\text { Bulk } \\
\text { density } \\
\left(\mathrm{Kg} / \mathrm{m}^{3}\right)\end{array}$} & \multirow{2}{*}{$\begin{array}{c}\text { Air } \\
\text { content } \\
(\%)\end{array}$} & \multicolumn{2}{|c|}{$\begin{array}{c}\text { Compressive } \\
\text { strength (MPa) } \\
\end{array}$} & \multicolumn{2}{|c|}{ Flexural strength (MPa) } \\
\hline & & & & & 2 days & 28 days & 2 days & 28 days \\
\hline $\mathbf{H C}$ & 0.42 & 141 & 2,201 & 5.2 & 14.9 & 39.0 & 4.1 & 7.8 \\
\hline OPC & 0.50 & 140 & 2,231 & 4.7 & 26.5 & 56.5 & 5.4 & 8.3 \\
\hline
\end{tabular}

\section{2.- Small-medium scale applications of H-Cement}

In a first practical trial conducted in 2013, a certain amount (a few $\mathrm{m}^{3}$ ) of concrete prepared with H-Cement was cast onto a small area reserved for a car park. The aim was to have a mid-sized slab on which to observe material performance when exposed to the elements. A certain degree of segregation was observed during concrete slab casting and construction. As a result, after the winter (a few months after concrete casting) a thin surface layer of concrete scaled and spalled. Nonetheless, at this writing, 6 years after the concrete was place, the H-Cement concrete slab shows no sign of cracking (Figure 10(a)). In short, this first experience with H-Cement was deemed to be so promising that it was used to optimise the water/cement ratio in H-Cements tested for other applications (in the next paragraphs some examples will be shown)

That same year -2013- a German company specialising in motorway and airport area repair asked Považská cementáreň to design and prepare a concrete to be used as pavement able to develop $20 \mathrm{MPa}$ strength in $12 \mathrm{~h}$. The standard dose of cement for the type of concrete requested would range from $350 \mathrm{~kg} / \mathrm{m}^{3}$ to $380 \mathrm{~kg} / \mathrm{m}^{3}$. The batching designed for the concrete used in the aforementioned works (where concrete was cast during the summer months at temperatures of $30^{\circ} \mathrm{C}$ ) is given in Table 4 . As the data show, the binder used in the concrete, a blend of $\mathrm{H}-$ Cement and $42.5 \mathrm{R}$ portland cement at a ratio of 30:70, comfortably met the strength requirement specified. 
Table 4. Concrete for summertime motorway repair

\begin{tabular}{|c|c|}
\hline Material & $\mathrm{kg} / \mathrm{m}^{3}$ \\
\hline CEM II/A-LL 42.5 R cement & 245 \\
\hline H-Cement & 105 \\
\hline Water & 120 \\
\hline BASF GLACE 420 & 2.45 \\
\hline${ }^{1} \mathrm{LP} 70$ & 0.7 \\
\hline X-SPEED BASF & 7.0 \\
\hline $0 \mathrm{~mm}$ to $4 \mathrm{~mm}$ aggregate & 629 \\
\hline $4 \mathrm{~mm}$ to $8 \mathrm{~mm}$ aggregate & 629 \\
\hline $8 \mathrm{~mm}$ to $16 \mathrm{~mm}$ aggregate & 393 \\
\hline $16 \mathrm{~mm}$ to $22 \mathrm{~mm}$ aggregate & 314 \\
\hline Total & 2442.4 \\
\hline $\mathrm{F} 2 \mathrm{~mm}$ & 410 \\
\hline $12 \mathrm{~h}$ compressive strength & $27.3 \mathrm{MPa}$ \\
\hline
\end{tabular}

${ }^{1} \mathrm{LP} 70$ additive was used to improve the concrete workability

A concrete with a CEM I $52.5 \mathrm{R}$ portland cement content of $370 \mathrm{~kg} / \mathrm{cm}^{3}$ and a $12 \mathrm{~h}$ target compressive strength of $20 \mathrm{MPa}$ routinely supplied by a German manufacturer for road repair has been shown to be prone to low workability and early age cracking, particularly when poured in hot weather.

In that context, advanced repair concrete design entailing the addition of small amounts of H-CEMENT to the mix proved to deliver remarkable benefits, including: i) the acceptable performance of lower strength class cement such as CEM I 42.5 R when used in conjunction with H-CEMENT; ii) less heat of hydration and early age cracking (as per published articles); iii) improved compaction (pilot tests); iv) lower $\mathbf{C O}_{2}$ emissions.

H-Cement is also particularly apt for concretes to be cast in warm weather. With HCement concrete, no problems arise even at temperatures of over $40{ }^{\circ} \mathrm{C}$. Hot, dry summers followed by a long rainy season have consistently caused severe damage to German motorways [86]. The main conclusion drawn from the use of H-Cement as a partial replacement for portland cement in motorway surface repair was that scant expansion joints were needed which should contribute to lengthening road service life [76]. 
Figure 10. (a) H-Cement concrete applications: car park (2013 - 2019), crack-free after 6 years; (b) and (c) H-Cement concrete dosed as shown in Table 5

Another promising feature of this material is its self-levelling capacity. The comparison between the characteristics of an H-Cement self-levelling floor to those laid with other types of materials in Table 5 shows that the former is highly suitable for such applications.

Table 5. Comparison of self-levelling flooring

\begin{tabular}{l|l|l|l}
\hline & $\begin{array}{l}\text { Anhydrite-based } \\
\text { mixes }\end{array}$ & Concrete mixes & H-concrete \\
\hline Flatness & $2 \mathrm{~mm} / 2 \mathrm{~m}$ & $5 \mathrm{~mm} / 2 \mathrm{~m}$ & $2 \mathrm{~mm} / 2 \mathrm{~m}$ \\
\hline Pumpability & Readily pumpable & Readily pumpable & Readily pumpable \\
\hline Bending strength & $<4 \mathrm{MPa}$ & $<4 \mathrm{MPa}$ & $<4 \mathrm{MPa}$ \\
\hline Compressive strength & $<20 \mathrm{MPa}$ & $15-25 \mathrm{MPa}$ & $>15 \mathrm{MPa}$ \\
\hline Remaining moisture & irrelevant & scant & scant \\
\hline $\begin{array}{l}\text { Intrinsic properties in } \\
\text { humid environments }\end{array}$ & not relevant & no effect & no effect \\
\hline Bug holes & no & yes & no \\
\hline Bleeding & no & yes & no \\
\hline Torsion/vulnerability & no & yes & no \\
\hline Plastic cracking & no & yes & no \\
\hline $\begin{array}{l}\text { Expansion } \\
\text { no }\end{array}$ & yes & $\begin{array}{l}\text { no, if concrete } \\
\text { well designed }\end{array}$ \\
\hline $\begin{array}{l}\text { Affected by air flow } \\
\text { curing }\end{array}$ & no & highly & scantly \\
\hline $\begin{array}{l}\text { Tile laying constraints } \\
\text { nolatemperature when }\end{array}$ & sealant required & $\begin{array}{l}\text { no sealant } \\
\text { required }\end{array}$ & $\begin{array}{l}\text { no sealant } \\
\text { required }\end{array}$ \\
\hline
\end{tabular}

On the other hand a well-known Slovakian manufacturer of autoclaved aerated concrete (AAC) replaced CEM I 42.5 R with H-Cement in all its products. The results show that $\mathrm{H}-\mathrm{Cement}$ is not only wholly apt for AAC manufacture, but that the new product has higher mechanical strength than the material made with CEM I 42.5 R.

\section{3.- Solutions to some common problems}

Based on the experience acquired in recent years, the problems commonly encountered with OPC and $\mathrm{H}$-Cement differ in certain significant ways, as do the respective 
solutions. The following is a brief description of the appearance of several common problems associated with H-Cement and how to address them.

\section{A) Efflorescence}

From the outset, H-Cement exhibited a certain tendency to generate efflorescence. The problem was solved, however, by optimising the water/cement ratio, and/or adding a small amount of ground limestone to the material and vibrating the fresh concrete immediately prior to casting. When the literature has occasionally dealt with efflorescence in alkaline cements [87-89] the conclusion drawn is that beyond the aesthetics involved, efflorescence has an adverse effect on the quality of the outer layer of concrete.

Some very limited efflorescence (no different than observed in portland cement) was observed to appear in H-Cement several years after casting. The present authors found that efflorescence in hybrid cement concretes is not only aesthetically and technologically detrimental, but an indication that cement hydration is not taking place optimally, normally due to environmental or mixing conditions.

\section{B) Alkali-Silica Reaction (ASR)}

The ASR can be a serious problem in many parts of the world [90-92]. The recommended ceiling for alkalis in ordinary portland cements used with potentially reactive aggregate for laying pavements is $\mathrm{Na}_{2} \mathrm{O}_{\text {eq. }}=0.8 \%$ [93]. Maintaining such constraints will lower the future availability of natural aggregate substantially in a context in which cement manufacture is becoming increasingly dependent upon alternative raw materials and fuels with a 'high' $\mathrm{Na}_{2} \mathrm{O}_{\text {eq. }}$ content.

The swelling reaction that prompts expansion and concomitant cracking in today's concretes (Equation 7) is less intense in H-Cement than in portland cement. In the former, all the alkalis present in the medium $\left[\mathrm{Na}_{2} \mathrm{O}_{\text {eq. }} .>0.8\right]$ are consumed to activate the aluminosilicates in the fraction of the alkaline cement included in the material. That constitutes an obvious and substantial advantage over $\mathrm{OPC}$, for $\mathrm{H}$-cement in fact inhibits the ASR (Figure 11) [94-95].

$$
2 \mathrm{NaOH}+\mathrm{SiO}_{2}+\mathrm{nH}_{2} \mathrm{O} \rightarrow \mathrm{Na}_{2} \mathrm{SiO}_{3} \times n \mathrm{H}_{2} \mathrm{O} \quad \text { Ec. } 7
$$


As the graph in Figure 11 shows, $180 \mathrm{~d}$ H-Cement mortar expansion stabilised at $0.020 \%$ and remained well under $0.100 \%$ throughout. The H-Cement suitability for mitigating alkali-aggregate reaction (AAR) was verified on the cement mortars according to STN 721179 Determination of the alkali-aggregate expansion (alkalisilica reaction) - the related ASTM Standards: C289 - 03 for chemical method; ASTM C1293 - 08b for length change of concrete.

Figure 11. Expansion in $180 \mathrm{~d}$ prismatic mortar specimens stored at $20^{\circ} \mathrm{C}$ or $40^{\circ} \mathrm{C}$ (HC=H-Cement mortar; PC = CEM I $42.5 \mathrm{~N}$ mortar; and HM=70\% $\mathrm{PC}$ and $30 \%$ HC)

\section{C) Chemical resistance}

$\mathrm{H}-\mathrm{Cement}$ has been classified and certified as a sulfate-resistant binder [96]. Tests in which $\mathrm{H}-\mathrm{Cement}$ was exposed to a highly aggressive environment $\left(5 \% \mathrm{Na}_{2} \mathrm{SO}_{4}\right)$ for 5 years revealed its exceptional chemical resistance (see Figure 12). That property may in fact lead to the penetration of new markets, such as oil well construction and waste water piping, to name just two of many.

Figure. 12. Sulfate-resistant

\section{E) Biodeterioration}

Concrete biodeterioration due to microbiological activity on the surface or inside the pore network should not be deemed to be a minor issue [97-99]. Concrete biocorrosion may shorten the material's service life drastically. The addition of ground granulated blast furnace slag (GGBFS) to portland cement is known to increase the material fungicidal properties [100] (Patent SK 288106). H-Cement also exhibits such properties. When tested for degree of fungal growth as described in Czech standard ČSN 72 4310: 1977 and compared to a commercial fungicide, it scored as 1 and the commercial fungicide as 0 . The interpretation of those results is as follows.

- 0-rated materials are apt for use in hospitals, food handling facilities, schools, kitchens, swimming pools and similar; and 
- 1-rated materials are apt for use in the timber industry, agriculture, water treatment plants, wine cellars and similar.

In short, biodeterioration is a new feature of hybrid cement with obvious positive implications for its technological and environmental value.

\section{CONCLUSIONS}

1.- The present findings constitute a considerable corpus of compositional and microstructural evidence attesting to a 'conceptual identity' between some of the lime+pozzolan cements used by the Romans 2000 years ago (the durability of which is beyond question) and the hybrid portland-alkaline cements presently under development. Among others, the evidence reveals the presence in both types of materials of C-A-S-H gels with zeolite- (or zeolite precursor)-like phases including alkalis in their structure, along with minority phases such as katoite, strätlingite and so on.

2.- There is a strong motivation to study the effect of time on hybrid cements to establish the compositional and microstructural differences and similarities with Roman cements to the necessary precision. Only now, 2000 years after they were made, are Roman cements beginning to be studied and understood in depth due to the recent application (during the research step) of very sophisticated, powerful and precise analysis devices.

3.- Technologically speaking, the hybrid cement studied (H-Cement) exhibits promising advantages over the traditional portland binder, including resistance to the alkaliaggregate reaction, chemical agents and fire, to name a few. Moreover, H-Cement can be produced on an industrial scale in the same facilities as portland cement, irrespective of the reasonable expectation that future research will lead to significant improvements in both manufacturing processes and the final product.

4.-From the perspective of sustainability this hybrid cement:

- emits significantly less $\mathrm{CO}_{2}$ than portland cement 
- is assumed to be compatible with a wide variety of aggregates recycled from industrial waste.

5.- The standards in place (in general) around the world should be revised rather sooner than later to include this type of binders (as well as some more new binders) as cements apt for commercial use.

\section{ACKNOWLEDGEMENTS}

Paulo Monteiro acknowledges the insightful discussions with G. Geng, K. Xu, J. Li, and T. Vanorio. He also thanks technical support given by Zeiss. Data acquired at beamlines 5.3.1 and 8.3.2 at the Advanced Light Source at the Lawrence Berkeley Laboratories, Berkeley, California, were supported by the Director of the Office of Science, Department of Energy, under Contract DEAC02-05CH11231. Angel Palomo and Ana Fernández-Jiménez acknowledge the financing support of the research to Spanish Ministry of the "Ciencia, Innovacion y Universidades and FEDER under research projects BIA2016-76466-R and RTC2016-4872-S.

\section{References}

[1] K.L. Scrivener, V.M. John, E.M. Gartner, Eco-efficient cements: Potential economically viable solutions for a low-CO2 cement-based materials industry, Cem. Concr. Res. 114 (2018) 2- 26. https://doi.org/10.1016/j.cemconres.2018.03.015.

[2] E. Gartner, T. Sui, Alternative cement clinkers, Cem. Concr. Res. 114 (2018) 2739. https://doi.org/10.1016/j.cemconres.2017.02.002.

[3] C. J. Brandon, R.L. Hohlfelder, M.D. Jackson and J.P. Oleson, Building for Eternity: The History and Technology of Roman Concrete Engineering in the Sea, Oxbow Books, Oxford, 2014.

[4] M. D. Jackson, J. Moon, E. Gotti, R. Taylor, S. R. Chae, M. Kunz, A.-H. Emwas, C. Meral, P. Guttmann, P. Levitz, H.-R. Wenk, P. J. M. Monteiro, Material and elastic properties of Al-tobermorite in ancient roman seawater concrete, J. Am. Ceram. Soc. 96 (8) (2013), 2598-2606. https://doi.org/10.1111/jace.12407.

[5] M.D. Jackson, G.Vola, D. Všianský, J.P. Oleson, B. Scheetz, C. Brandon, R. Hohlfelder, Cement microstructures and durability in ancient roman seawater concretes, in: J. Valek, C. Groot, and J. Hughes (Eds.), Historic Mortars. Characteristics and Tests, Springer-RILEM, Berlin, 2012, pp. 49-76.

[6] M. D. Jackson, S. R. Mulcahy, H. Chen, Y. Li, Q. Li, P. Cappelletti, H.-R. Wenk, Phillipsite and Al-tobermorite mineral cements produced through low-temperature water-rock reactions in Roman marine concrete, American Mineralogist, 102 (7) (2017) 1435-1450. https://doi.org/10.2138/am-2017-5993CCBY.

[7] V.M. Malhotra, P.K. Mehta, Pozzolanic and Cementitious Materials, Advances in Concrete Technology, Taylor and Francis, Oxon, UK, 1996. 
[8] S. Alonso, A. Palomo, Alkaline activation of metakaolin and calcium hydroxide mixtures: Influence of temperature, activator concentration and solids ratio, Mater. Lett. 47 (1-2) (2001) 55-62. https://doi.org/10.1016/S0167-577X(00)00212-3.

[9] S. Donatello, A. Fernández-Jiménez, A. Palomo, Very high volumen fly ash cements. Early age hydration study using Na2SO4 as an activator, J. Am. Ceram. Soc. 96 (3) (2013) 900-906. https://doi.org/10.1111/jace.12178.

[10] I. García-Lodeiro, A. Fernández-Jiménez, A. Palomo, Variation in hybrid cements over time. Alkaline activation of fly ash-portland cement blends, Cem. Concr. Res. 52 (2013) 112-122. https://doi.org/10.1016/j.cemconres.2013.03.022.

[11] S. Alahrache, F. Winnefeld, J.-B. Champenois, F. Hesselbarth, B. Lothenbach, Chemical activation of hybrid binders based on siliceous fly ash and Portland cement, Cem. Concr. Compos. 66 (2016) 10-23. https://doi.org/10.1016/j.cemconcomp.2015.11.003.

[12] I. Garcia-Lodeiro, A. Fernández-Jiménez, A. Palomo, D. E. Macphee, Effect on fresh $\mathrm{C}-\mathrm{S}-\mathrm{H}$ gels of the simultaneous addition of alkali and aluminium, Cem. Concr. Res. 40 (1) (2010) 27-32. https://doi.org/10.1016/j.cemconres.2009.08.004.

[13] I. Garcia-Lodeiro, A. Palomo, A. Fernández-Jiménez, D. E. Macphee, Compatibility studies between $\mathrm{N}-\mathrm{A}-\mathrm{S}-\mathrm{H}$ and $\mathrm{C}-\mathrm{A}-\mathrm{S}-\mathrm{H}$ gels. Study in the ternary diagram Na2O-CaO-Al2O3-SiO2-H2O, Cem. Concr. Res. 41 (9) (2011) 923-931. https://doi.org/10.1016/j.cemconres.2011.05.006.

[14] J.M. Mejía, E. Rodríguez, R. Mejía de Gutierrez, N. Gallego, Preparation and characterization of a hybrid alkaline binder based on a fly ash with no commercial value, J. of Cleaner Production $104 \quad$ (2015) 346e352. http://dx.doi.org/10.1016/j.jclepro.2015.05.044.

[15] W. Al-Kutti, M. Nasir, M. Azmi, M. Johari, A.B.M. Saiful Islam, A.A. Manda, N.I. Blaisi, An overview and experimental study on hybrid binders containing date palm ash, fly ash, OPC and activator composites. Construction and Building Materials 159 (2018) 567-577. https://doi.org/10.1016/j.conbuildmat.2017.11.017.

[16] R. Kajaste, M. Hurme, Cement industry greenhouse gas emissions management options and abatement cost, J. of Cleaner Production 112 (2016) 4041e4052. https://doi.org/10.1016/j.jclepro.2015.07.055.

[17] R. Maddalena, J.J. Roberts, A. Hamilton, Can Portland cement be replaced by lowcarbon alternative materials? A study on the thermal properties and carbon emissions of innovative cements, J. of Cleaner Production $186 \quad$ (2018) 933e942. https://doi.org/10.1016/j.jclepro.2018.02.138

[18] M. E. Blake, E. B. Van Deman, Ancient Roman Construction in Italy from the Prehistoric Period to Augustus, Smithsonian Institution, Washington DC, 1947.

[19] W. L. MacDonald, The Architecture of the Roman Empire: An Introductory Study, Rev. Ed., New Haven and London Yale University Press, 1982.

[20] H. O. Lamprecht, Opus Caementitium. Bautechnik der Römer, 5th edn., BetonVerlag, Düsseldorf, 1996.

[21] J. DeLaine, Building the Eternal City: the construction industry of imperial Rome, in: J. C. N. Coulston, H. Dodge (Eds.), Ancient Rome: the archaeology of the eternal city, Oxford University Committee for Archaeology, Oxford, 2000, pp. 119-141.

[22] L. C. Lancaster, Concrete Vaulted Construction in Imperial Rome: Innovations in Context. Cambridge: Cambridge University Press Lancaster, L. C. The process of building the Colosseum, Journal of Roman Archaeology 18 (2005) 57-82.

[23] E. D'Ambrosio, F. Marra, A. Cavallo, M. Gaeta, G. Ventura, Provenance materials for Vitruvius' harenae fossiciae and pulvis puteolanis: Geochemical signature 
and historical-archaeological implications, Journal of Archaeological Science: Reports, 2 (2015) 186-203. https://doi.org/10.1016/j.jasrep.2015.01.012.

[24] M. D. Jackson, S. R. Chae, S. R. Mulcahy, C. Meral, R. Taylor, P. Li, A.-H. Emwas, J. Moon, S. Yoon, G. Vola, H.-R. Wenk, P. J. M. Monteiro, Unlocking the secrets of Al-tobermorite in Roman seawater concrete, American Mineralogist, 98 (10) (2013) 1669-1687. https://doi.org/10.2138/am.2013.4484.

[25] M. D. Jackson, E. N. Landis, P. F. Brune, M. Vitti, H. Chen, Q. Li, M. Kunz, H.R. Wenk, P. J. M. Monteiro, A. R. Ingraffea, Mechanical resilience and cementitious processes in Imperial Roman architectural mortar, Proceedings of the National Academy of Sciences of the United States of America 111 (52) (2014) 18484-18489. https://doi.org/10.1073/pnas.1417456111.

[26] F. Marra, M. Anzidei, A. Benini, E. D'Ambrosio, M. Gaeta, G. Ventura, A. Cavallo, Petro-chemical features and source areas of volcanic aggregates used in ancient Roman maritime concretes, Journ. Volcan. Geoth. Res. 328 (2016) 59-69. https://doi.org/10.1016/j.jvolgeores.2016.10.005.

[27] S.R. Chae, J. Moon, S. Yoon, S. Bae, P. E. Levitz, R. P. Winarski, P. J. M. Monteiro, Advanced Nanoscale Characterization of Cement Based Materials Using Xray Synchrotron Radiation: A Review, International Journal of Concrete Structures and Materials 7 (2) (2013) 95-110. https://doi.org/10.1007/s40069-013-0036-1 .

[28] G. Geng, J. Li, Y.-S. Yu, D. A. Shapiro, D.A. L. Kilcoyne, P. J. M. Monteiro, Nanometer-Resolved Spectroscopic Study Reveals the Conversion Mechanism of $\mathrm{CaO} \cdot \mathrm{A} 12 \mathrm{O} 3 \cdot 10 \mathrm{H} 2 \mathrm{O}$ to $2 \mathrm{CaO} \cdot \mathrm{Al} 2 \mathrm{O} 3 \cdot 8 \mathrm{H} 2 \mathrm{O}$ and $3 \mathrm{CaO} \cdot \mathrm{Al} 2 \mathrm{O} 3 \cdot 6 \mathrm{H} 2 \mathrm{O}$ at an Elevated Temperature, Crystal Growth \& Design, 17 (8) (2017) 4246-4253. https://doi.org/10.1021/acs.cgd.7b00553 .

[29] G. Geng, R.J. Myers, J. Li, R. Maboudian, C. Carraro, D. A. Shapiro, P. J. M. Monteiro, Aluminum-induced dreierketten chain cross-links increase the mechanical properties of nanocrystalline calcium aluminosilicate hydrate, Scientific Reports, 7 (2017). https://doi.org/10.1038/srep44032 .

[30] G. Geng, R. J. Myers, M. J. A. Qomi, P. J. M. Monteiro, Densification of the interlayer spacing governs the nanomechanical properties of calcium-silicate-hydrate, Scientific Reports, 7 (2017). https://www.nature.com/articles/s41598-017-11146-8.

[31] R. J. Myers, G. Geng, J. Li, E. D. Rodríguez, J. Ha, P. Kidkhunthod, G. Sposito, L. N. Lammers, A. P. Kirchheim, P. J. M. Monteiro, Role of Adsorption Phenomena in Cubic Tricalcium Aluminate Dissolution, Langmuir 33 (1) (2017) 45-55. https://doi.org/10.1021/acs.langmuir.6b03474 .

[32] J. Li, G. Geng, R. Myers, Y.-S. Yu, D. Shapiro, C. Carraro, R. Maboudian, P. J. M. Monteiro, The chemistry and structure of calcium (alumino) silicate hydrate: A study by XANES, ptychographic imaging, and wide- and small-angle scattering, Cem. Concr. Res. 115 (2019) 367-378. https://doi.org/10.1016/j.cemconres.2018.09.008.

[33] C. White, K. Page, N.J. Henson, J. Provis, In Situ Synchrotron X-ray Pair Distribution Function Analysis of the Early Stages of Gel Formation in MetakaolinBased Geopolymers, Clay Science $73 \quad$ (2013) 03. https://doi.org/10.1016/j.clay.2012.09.009

[34] A.C. Jupe, X. Turrillas, P. Barnes, S.L. Colston, C. Hall, D. Häusermann, and M. Hanfland, Fast in situ x-ray-diffraction studies of chemical reactions: A synchrotron view of the hydration of tricalcium aluminate, Phys. Rev. B 53, (1996).R14697(R). https://doi.org/10.1103/PhysRevB.53.R14697

[35] M.A.G Aranda., Recent studies of cements and concretes by synchrotron radiation crystallographic and cognate methods, Crystallography Reviews, 22, (2016) 150-196 https://doi.org/10.1080/0889311X.2015.1070260 
[36] W. P. Gates, J. G. Sanjayan, F. Collins, NMR, XRD, IR and synchrotron NEXAFS spectroscopic studies of OPC and OPC/slag cement paste hydrates, Materials and Structures, 44, (2011), 1773-1791. https://doi.org/10.1617/s11527-011-9737-6

[37] A. Mesbah, M. François, C. Cau-dit-Coumes, F. Frizon, Y. Filinchuk, F. Leroux, J. Ravaux, G. Renaudin, Crystal structure of Kuzel's salt $3 \mathrm{CaO} \cdot \mathrm{Al} 2 \mathrm{O} 3 \cdot 1 / 2 \mathrm{CaSO} 4 \cdot 1 / 2 \mathrm{CaCl} 2 \cdot 11 \mathrm{H} 2 \mathrm{O}$ determined by synchrotron powder diffraction, Cem. Concr. Res. 41, 5, (2011), 504-509, https://doi.org/10.1016/j.cemconres.2011.01.015

[38] J. R. Hale, Beyond the eternal city: Roman concrete in global perspective, in: A. Ringborn, R.L. Hohfelder (Eds.) Proceeding of the conference Building Roma Aeterna, 2008.

[39] T. Frank, Roman Buildings of the Republic: An Attempt to Date Them from Their Materials. American Academy in Rome, Rome, 1924.

[40] J. P. Oleson, C. Brandon, S. M. Cramer, R. Cucitore, E. Gotti, R. L. Hohlfelder, The ROMACONS project: a contribution to the historical and engineering analysis of hydraulic concrete in Roman maritime structures, Int. J. Naut. Archaeol. 33 (2) (2004) 199-229. https://doi.org/10.1111/j.1095-9270.2004.00020.x

[41] D. Miriello, D. Barca, A. Bloise, A. Ciarallo, G.M. Crisci, F. De Rose, C. Gattuso, F. Gazineo, M. F. La Russa, Characterization of archaeological mortars from Pompeii (Campania, Italy) and identification of construction phases by compositional data analysis. J. Archaeol. Sci. $37 \quad$ (9) (2010) 2207-2223. https://doi.org/10.1016/j.jas.2010.03.019

[42] M. D. Jackson, D. Deocampo, F. Marra, B. Scheetz, Mid-Pleistocene volcanic ash in ancient Roman concretes, Geoarchaeology 25 (1) (2010) 36-74. DOI: 10.1002/gea.20295.

[43] M. D. Jackson, C. Kosso, F. Marra, R.L. Hay, Geological basis of Vitruvius' empirical observations of material characteristics of rock utilized in Roman masonry, in: M. Dunkeld, J. Campbell, H. Louw, M. Tutton, B. Addis, R. Thorne (Eds.), Proceedings of the Second International Congress of Construction History, Queen's College, University of Cambridge, The Construction History Society, London, 2006, pp. 1685-1702.

[44] M. D. Jackson, F. Marra, D. M. Deocampo, A. Vella, C. Kosso, R. L. Hay, Geological observations of excavated sand (harena fossiciae) used as fine aggregate in Ancient Roman pozzolanic mortars, J. Roman. Archaeol. 20 (1) (2007) 1-30. DOI: $10.1017 /$ S1047759400005304.

[45] F. Marra, E. D'Ambrosio, G. Sottili, G. Ventura, Geochemical fingerprints of volcanic materials: Identification of a pumice trade route from Pompeii to Rome, Geological Society of America Bulletin 125 (3-4) (2013) 556-577. DOI: 10.1130/B30709.1.

[46] F. Marra, M. Anzidei, A. Benini, E. D'Ambrosio, M. Gaeta, G. Ventura, A. Cavallo, Petro-chemical features and source areas of volcanic aggregates used in ancient Roman maritime concretes, Journal of Volcanology and Geothermal Research 328 (2016) 59-69. https://doi.org/10.1016/j.jvolgeores.2016.10.005.

[47] J. P. Oleson, Harena sine Calce: Building disasters, incompetent architects, and construction fraud in ancient Rome, in: A. Aeterna, Ringborn, R.L. Hohfelder (Eds.), Proceeding of the conference Building, Roma, 2008.

[48] G. Vola, E. Gotti, C. Brandon, J. P. Oleson, R. L. Hohlfelder, Chemical, mineralogical and petrographic characterization of Roman ancient hydraulic concretes cores from Santa Liberata, Italy, and Caesarea Palestinae, Israel, Period. di Mineral. 80 (2) (2011) 317-338. DOI: 10.2451/2011PM0023. 
[49] E. Gotti, J. P. Oleson, L. Bottalico, C. Brandon, R. Cucitore, R. L. Hohlfelder, A comparison of the chemical and engineering characteristics of ancient roman hydraulic concrete with a modern reproduction of vitruvian hydraulic concrete, Archaeometry 50 (4) (2008) 576-590. https://doi.org/10.1111/j.1475-4754.2007.00371.x.

[50] J.T. MacFarlane, Personal Communications, 2019.

[51] F. Massazza, Concrete resistance to seawater and marine environment, Il Cemento 1 (1985) 3-25.

[52] S. Bae, R. Taylor, D. Shapiro, P. Denes, J. Joseph, R. Celestre, S. Marchesini, H. Padmore, T. Tyliszczak, T. Warwick, D. Kilcoyne, P. Levitz, P. J. M. Monteiro, Soft Xray Ptychographic Imaging and Morphological Quantification of Calcium Silicate Hydrates (C-S-H), J. Am. Ceram. Soc. 98 (12) (2015) 4090-4095. https://doi.org/10.1111/jace.13808

[53] G. Geng, R. J. Myers, A. L. D. Kilcoyne, J. Ha, P. J. M. Monteiro, Ca L2, 3-edge near edge X-ray absorption fine structure of tricalcium aluminate, gypsum, and calcium (sulfo) aluminate hydrates, American Mineralogist 102 (4) (2017) 900-908. https://doi.org/10.2138/am-2017-5670.

[54] Y.S. Yu, M. Farmand, C. Kim, Y. Liu, C.P. Grey, F.C. Strobridge, T. Tyliszczak, R. Celestre, P. Denes, J. Joseph, H. Krishnan, F.R.N.C. Maia, A.L.D. Kilcoyne, S. Marchesini, T.P.C. Leite, T. Warwick, H. Padmore, J. Cabana, D.A. Shapiro, Threedimensional localization of nanoscale battery reactions using soft X-ray tomography, Nature Communications 9, Article number: 921 (2018). https://doi.org/10.1038/s41467018-03401-x

[55] T. Vanorio, W. Kanitpanyacharoen, Rock physics of fibrous rocks akin to Roman concrete explains uplifts at Campi Flegrei Caldera, Science 349 (6248) (2015) 617-621. DOI: $10.1126 /$ science.aab1292.

[56] C. Biagioni, S. Merlino, E. Bonaccorsi, The tobermorite supergroup: A new nomenclature, Mineralogical Magazine $79 \quad$ (2) (2015) 485-495. https://doi.org/10.1180/minmag.2015.079.2.22.

[57] H. F. W. Taylor, Cement chemistry, Thomas Telford Publishing, London, 1997.

[58] A. Palomo, A. Fernández-Jiménez, G. Kovalchuk, L. M. Ordoñez, M. C. Naranjo, OPC-Fly ash cementitious system: study of the gel binder produced during alkaline hydration, J. of Mater. Sci. 42 (9) (2007) 2958-2966. http://dx.doi.org/10.1007/s10853006-0585-7.

[59] I. Garcia-Lodeiro, A. Fernandez-Jimenez, A. Palomo, D. E. Macphee, Effect of calcium additions on N-A-S-H cementitious gels, J. Am. Ceram. Soc. 93 (7) (2010) 1934-1940. https://doi.org/10.1111/j.1551-2916.2010.03668.x.

[60] I. Garcia-Lodeiro, S. Donatello, A. Fernández-Jiménez, A. Palomo, Hydration of hybrid alkaline cement containing a very large proportion of fly ash: A descriptive model, Materials, 9 (7) (2016) 605. https://doi.org/10.3390/ma9070605.

[61] Z. Abdollahnejad, P. Hlavacek, S. Miraldo, F. Pacheco-Torgal, J.L.B. De Aguiar, Compressive strength, microstructure and hydration products of hybrid alkaline cements, Materials Research, 2014, 17(4), pp. 829-837. http://dx.doi.org/10.1590/S1516-14392014005000091

[62] B. Qu, A. Martin, J.Y. Pastor, , A. Palomo, A. Fernández-Jiménez, Characterisation of pre-industrial hybrid cement and effect of pre-curing temperature. Cem. Concr. Comp. 73, (2016), 281-288. https://doi.org/10.1016/j.cemconcomp.2016.07.019.

[63] M. Askarian, Z. Tao, G. Adam, B. Samali, Mechanical properties of ambient cured one-part hybrid OPC-geopolymer concrete, Construction and Building Materials 186, (2018) 330-337. https://doi.org/10.1016/j.conbuildmat.2018.07.160. 
[64] P. Faucon, A. Delagrave, C. Richet, J. M. Marchand, H. Zanni, Aluminium incorporation in calcium silicate hydrates $(\mathrm{C}-\mathrm{S}-\mathrm{H})$ depending on their $\mathrm{Ca} / \mathrm{Si}$ ratio, J. Phys. Chem. B. 103 (37) (1999) 7796-7802. DOI: 10.1021/jp990609q.

[65] I. G. Richardson, A. R. Brough, R. Brydson, G. W. Groves, C. M. Dobson, Location of aluminium in substituted calcium silicate hydrate (C-S-H) gels as determined by 29Si and 27Al NMR and EELS, J. Am. Ceram. Soc. 76 (9) (1993) 22852288. https://doi.org/10.1111/j.1151-2916.1993.tb07765.x.

[66] A. Fernández-Jiménez, F. Puertas, I. Sobrados, J. Sanz, Structure of calcium silicate hydrated formed in alkali-activated slag: Influence of the type of alkaline activator, J. Am. Ceram. Soc. 86 (8) (2003) 1389-1394. https://doi.org/10.1111/j.11512916.2003.tb03481.x.

[67] F. Puertas, M. Palacios, H. Manzano, J. S. Dolado, A. Rico, J. Rodríguez, A model for the C-A-S-H gel formed in alkali-activated slag cements, J. of European Ceramic Soc. 31 (12) (2011) 2043-2056. https://doi.org/10.1016/j.jeurceramsoc.2011.04.036.

[68] R. J. Myers, S. A. Bernal, R. San Nicolas, J. L. Provis, Generalized Structural Description of Calcium-Sodium Aluminosilicate Hydrate Gels: The Cross-Linked Substituted Tobermorite Model, Langmuir 29 (17) (2013) 5294-5306. DOI: 10.1021/la4000473.

[69] R. J. Myers, S. A. Bernal, J.D. Gehman, J. S. J. van Deventer, J. L. Provis, The role of Al in cross-linking of alkali-activated slag cements, J. Am. Ceram. Soc. 98 (3) (2015) 996-1004. https://doi.org/10.1111/jace.13360

[70] B. Walkley, R. San Nicolas, M.A. Sani, G.J. Rees, J.V. Hanna, J.S.J. van Deventer, J.L. Provis, Phase evolution of C-(N)-A-S-H/N-A-S-H gel blends investigated via alkali-activation of synthetic calcium aluminosilicate precursors, Cem. Concr. Res. 89 (2016) 120-135. https://doi.org/10.1016/j.cemconres.2016.08.010

[71] E. L'Hôpitala, B. Lothenbacha,K.Scrivenerc,D.A.Kulik, Alkali uptake in calcium alumina silicate hydrate (C-A-S-H), Cem. Concr. Res. 85 (2016) 122-136. https://doi.org/10.1016/j.cemconres.2016.03.009

[72] J. N. Yankwa Djobo, A. Elimbi, H. Kouamo Tchakouté, S. Kumar, Volcanic ashbased geopolymer cements/concretes: the current state of the art and perspectives, Environmental Science and Pollution Research 24 (5) (2016) 4433-4446. DOI: 10.1007/s11356-016-8230-8.

[73] S. L. Poulsen, V. Kocaba, G. Le Saou^t, H. J. Jakobsen, K. L. Scrivener, J. Skibsted, Improved quantification of alite and belite in anhydrous Portland cements by 29Si MAS NMR: Effects of paramagnetic ions, Solid State Nucl. Magn. Reson. 36 (1) (2009) 32-44. https://doi.org/10.1016/j.ssnmr.2009.05.001.

[74] Garcia-Lodeiro, I., Fernández-Jimenez, A., Palomo, A., Cements with a low clinker content: Versatile use of raw materials, Journal of Sustainable Cement-Based Materials, 2015, 4(2), pp. 140-151. https://doi.org/10.1080/21650373.2015.1040865 [75] G. Vola M.D. Jackson, J.P. Oleson, C. Brandon, R.L. Hohlfelder, Mineralogical and Petrographic characterization of ancient roman maritime concretes from mediterranean harbours,. 2nd Historic Mortars Conference HMC2010 and RILEM TC 203-RHM final workshop 22-24, September 2010, Prague, Czech Republic. .381-388

[76] P. Martauz, I. Janotka, J. Strigac, M. Bacuvcik, Fundamental properties of industrial hybrid cement: utilization in ready mix concretes and shrinkage reducing applications, Materiales de Construccion $66 \quad$ (322) (2016). http://dx.doi.org/10.3989/mc.2016.04615.

[77] K. Scrivener, A. Nonat, Hydration of cementitious materials, present and future, Cement and Concrete Research 41 (2011) 651-665, doi:10.1016/j.cemconres.2011.03.026 
[78] S.A. Bernal and J.L. Provis, Durability of Alkali-Activated Materials: Progress and Perspectives, J. Am. Ceram. Soc., 97 [4] (2014) 997-1008. https://doi.org/10.1111/jace.12831.

[79] F. Massazza, Pozzolana and pozzolanic cements, in: Hewlett ed., Lea's Chemistry of Cement and Concrete, 4th Ed., Arnold, London, 1988, pp. 471-632.

[80] F. Massazza, Properties and applications of natural pozzolanas, in: J. Bensted, P. Barnes (Eds.), Structure and Performance of Cements, 2nd Ed., Taylor and Francis, London, 2002, pp. 326-352.

[81] J. Skibsted, E. Henderson, H. J. Jakobsen, Characterization of calcium aluminate phases in cements by 27Al MAS NMR spectroscopy, Inorg. Chem. 32 (6) (1993) 10131027. DOI: $10.1021 / \mathrm{ic} 00058 \mathrm{a} 043$.

[82] P. Faucon, T. Charpentier, D. Bertrandie, A. Nonat, J. Virlet, J. C. Petit, Characterization of calcium aluminate hydrates and related hydrates alkaline hydration of tricalcium aluminate of cement pastes by 27Al MQ-MAS NMR, Inorg. Chem. 37 (15) (1998) 3726-3733. DOI: 10.1021/ic9800076.

[83] M. D. Andersen, H. J. Jakobsen, J. Skibsted, A new aluminium-hydrate species in hydrated Portland cement characterized by 27Al y 29Si MAS NMR spectroscopy, Cem. Concr. Res. 36 (1) (2006) 3-17. https://doi.org/10.1016/j.cemconres.2005.04.010.

[84] S. Kwan, J. LaRosa and M.W. Grutzeck 29Si and 27Al MASNMR study of Strätlingite. J. Am. Ceramic. Soc. 78 (1995)1921-1926. https://doi.org/10.1111/j.11512916.1995.tb08910.x

[85] Patent SK 288418 (2016). Kombinované spojivo na baze odpadov. Granted on August 10th 2016.

[86] Welt. Tödliches Blow-up auf deutschen Autobahnen

A93. https://www.welt.de/wissenschaft/article117315923/Toedliches-Blow-up-aufdeutschen-Autobahnen.html (accessed 20 June 2013)

[87] C. Dow, F.P. Glasser, Calcium carbonate efflorescence on Portland cement and building materials, Cem. Concr. Res. 33 (1) (2003) 147-154. https://doi.org/10.1016/S0008-8846(02)00937-7.

[88] Z. Zhang, J.L. Provis, A. Reid, H. Wang, Fly ash based geopolymers: the relationship between composition, pore structure and efflorescence. Cem. Concr. Res. 64 (2014) 30-41. https://doi.org/10.1016/j.cemconres.2014.06.004.

[89] Z. Zhang, J.L. Provis, X. Ma, A. Reid, H. Wang, Efflorescence and subflorescence induced microstructural and mechanical evolution in fly ash-based geopolymers, Cem. $\begin{array}{llll}\text { Concr. Compos. } & 92 & \text { (2018) }\end{array}$ https://doi.org/10.1016/j.cemconcomp.2018.06.010.

[90] L.S. Dent Glasser, N. Kataoka, On the role of calcium in the alkali-aggregate reaction, Cem. Concr. Res. 12 (3) (1982) 321-331. https://doi.org/10.1016/00088846(82)90080-1.

[91] M.H. Shehata, M.D.A. Thomas, The effect of fly ash composition on the expansion of concrete due to alkali-silica reaction, Cem. Concr. Res. 30 (7) (2000) 1063-1072. https://doi.org/10.1016/S0008-8846(00)00283-0.

[92] S. Beauchemin, B. Fournier, J. Duchesne, Evaluation of the concrete prisms test method for assessing the potential alkali-aggregate reactivity of recycled concrete $\begin{array}{llllll}\text { aggregates, } & \text { Cem. } & \text { Concr. } & \text { Res. } & 104 & \text { (2018) }\end{array}$ https://doi.org/10.1016/j.cemconres.2017.10.008.

[93] Povazska cementaren - TSUS Bratislava 2015. Resistance of H-Cement to alkalisilica reaction. Final report 20-15-0200/4. Issued 4th December 2015. 
[94] Fernández-Jiménez A., Puertas F., The alkali-silica reaction in alkali activated granulated slag mortars with reactive aggregate, Cem. Concr. Res. 32 (2002) 10191024.

[95] García-Lodeiro I., Palomo A., and Fernández-Jiménez A., (2007), “The alkaliaggregate reactions in alkali activated fly ash mortars" Cem. Concr. Res. 37, [2], 175$183 \mathrm{https} / / /$ doi.org/10.1016/j.cemconres.2006.11.002.

[96] I. Janotka, P. Martauz, M. Bacuvcik, Resistance of hybrid cement after 5-years exposure to $5 \% \mathrm{Na} 2 \mathrm{SO} 4,14$ th Int. Conf. on advance concrete technology and sustainable issues, Beijing, 2018.

[97] M. Sanchez-Silva, D. V. Rosowsky, Biodeterioration of construction materials: state of the art and future challenges, J. Mater. Civil Eng. 20 (5) (2008), 352-365. https://doi.org/10.1061/(ASCE)0899-1561(2008)20:5(352).

[98] C. Magniont, M. Coutand, A. Bertron, X. Cameleyre, C. Lafforgue, S. Beaufort, G. Escadeillas, A new test method to assess the bacterial deterioration of cementitious materials, Cem. Concr. Res. 41 (4) (2011) 429-438. https://doi.org/10.1016/j.cemconres.2011.01.014.

[99] T. D. Dyer, Biodeterioration of concrete, CRC Press by Taylor and Francis Group, 2017. https://doi.org/10.1201/9781315119557.

[100] J. Strigac, P. Martauz, A. Estokova, N. Stevulova, A. Luptakova, Bio-Corrosion Resistance of Concretes Containing Antimicrobial Ground Granulated Blast furnace Slag BIOLANOVA and Novel Hybrid H-Cement, Solid State Phenomena 244 (2015) 57-64. https://doi.org/10.4028/www.scientific.net/SSP.244.57. 